\title{
PRIMORSKI BUNJEVCI KRIVOPUĆANI NA PODRUČJU VIROVITICE
}

\author{
Marijeta RAJKOVIĆ \\ Filozofski fakultet Sveučilišta u Zagrebu \\ Odsjek za etnologiju i kulturnu antropologiju \\ Ivana Lučića 3, 10000 Zagreb \\ Jasmina JURKOVIĆ \\ Gradski muzej Virovitica \\ Dvorac Pejačević \\ 33000 Virovitica
}

\section{UVOD}

$\mathrm{M}$ igracije se kao predmet istraživanja počinju javljati u spisima ranih teoretičara stanovništva u 19. stoljeću (Mesić 2002: 271). No, (socio)kulturna antropologija je kao znanost relativno kasno počela proučavati migracije. Etnolozi i/ili sociokulturni antropolozi nisu pisali o migracijskim mobilnostima jer se nisu uklapale u bezvremensku ideju kulture. Međutim, krajem pedesetih i početkom šezdesetih godina 20. stoljeća teme iz migracija stanovništva počinju se sistematičnije proučavati. Zanimanje za migrante i migracije raslo je usporedno s povećanjem studija o ruralnoj i urbanoj antropologiji, stoga su se u ovom razdoblju istraživale ponajviše ruralno-urbane migracije, točnije proučavanje "seljaka" i "domorodaca" u gradovima. Zanimanje za ovu temu raslo je osamdesetih i devedesetih godina 20. stoljeća, kada migracije postaju nezaobilazna tema sociokulturnih antropologa, odnosno etnologa (usp. Brettell 2003:1-2).

Kako saznajemo na internetskim stranicama Instituta za migracije i narodnosti u istraživanjima suvremenih unutarnjih migracija u Hrvatskoj razlikujemo dva tipa. Jedan tip predstavlja nastavak tradicionalnih migracijskih tokova unutar Hrvatske izmedu njenih emigracijskih, prvenstveno brdsko-planinskih, otočnih $i$ ruralnih prostora prema glavnim sredistima makroregija $i$ djelomice općinskim centrima, dok je drugi tip posljedica ratne agresije na Hrvatsku. U prvom se slučaju govori o migracijama kao procesu unutar regularnog demografskog razvitka, dok su druge ratne tj. prisilne migracije (usp. http://www.imin. $\mathrm{hr} /$ page/index.aspx? $\mathrm{r}=2 \& \mathrm{r} 1=11)$.

$$
* * *
$$

$\mathrm{O}$ unutarnjim migracijama na području Hrvatske pisali su ponajviše sociolozi, demografi te pojedini hrvatski etnolozi. Fokus njihovih radova na teme migracijskih mobilnosti bio je usmjeren ponajviše na migracije otoci - kopno, zatim ruralno - urbane (selo - grad), te prisilne migracije. U ovom radu prikazuje se studija slučaja dobrovoljnih, homogenih migracija zbog ekonomskih razloga iz jedne u drugu regiju na prostoru Republike Hrvatske.

Višekratna istraživanja (2002.-2006.) na području Senjskoga bila, Krivoga Puta, Krasna i dijelu Podgorja (Gornja Klada i Babrovača) rezultirala su obradom tema iz materijalne, duhovne i društvene kulture. Tako su istraživane i migracije stanovništva u vremenskom periodu od kraja 19. stoljeća i tijekom 20. stoljeća $^{2}$. Zapaženo je kako je velik dio stanovništva s primorske strane podno Velike Kapele te sjevernoga

Rad je u neznatno izmijenjenoj varijanti objavljen u Studia ethnologica Croatica, vol. 18, 2006. godine.

2 Vidi radove M. Rajković: Prilozi poznavanju migracija Krivopućana, Senjski zbornik, 31, Senj, 2004., 261-286.; Sezonske migracije na području Krivoga Puta: tradicija u recentnoj povijesnoj perspektivi, Senjski zbornik, 32, 2005., str. 273-316; Istraživanje migracija primorskih Bunjevaca na virovitičko područje, Baština, 2., Virovitica (u tisku). 
Velebita odlazio na privremene, odnosno sezonske radove na razna područja Slavonije. Značajan dio njih ostajao je ondje živjeti. Ovaj rad usmjeren je samo na primjer migracija s područja Krivoga Puta, s naglaskom na razdoblje dvadesetih i tridesetih godina 20. stoljeća kada su migracije bile najmasovnije ${ }^{3}$. Nakon privremenih višegodišnjih odlazaka na područja Virovitice Krivopućani su ondje postupno ostajali živjeti, točnije formirali su naselje Rezovačke Krčevine, te kupovali zemljišta u naselju Podgorje.

Istraživanje migracija Krivopućana u virovitičku okolicu provedeno je kroz više navrata i s nekoliko aspekata. Višekratnim boravkom u Krivome Putu (2003.-2006.) istraživalo se o odlascima Krivopućana na privremene radove na područje Virovitice, zatim o komunikaciji kako sa samim migrantima tako i njihovim potomcima, o posjetima istih, obnavljanju obiteljskih kuća, te gradnji kuća za odmor kako na području Krivoga Puta, tako i bližim turističkim atraktivnijim mjestima ${ }^{4}$. Druga faza provođena je na području Virovitice kroz razgovore s potomcima doseljenih Krivopućana u srpnju 2005. godine prilikom gostovanja članova Nogometnog kluba "Bunjevac" iz Krivoga Puta kod domaćina Nogometnog kluba "Podgorje" iz Podgorja, te u nekoliko navrata tijekom 2005. i 2006. godine 5 . Treća faza zajedničko je istraživanje autorica na području Rezovačkih Krčevina, Podgorja i grada Virovitice ${ }^{6}$. Tom prigodom razgovaralo se s migranatima i njihovim potomcima, a primarni je cilj bio saznati o procesima njihova uklapanja u novu sredinu te povezanosti s Krivim Putem.

Migracije su multidisciplinarno područje istraživanja ${ }^{7}$. Mnoge struke žele odgovoriti na ključna pitanja: zašto se ljudi sele, tko se seli $i$ što se dogada nakon što se presele? (usp. Brettell 2003:1-7). Na ta pitanja daju se odgovori i u ovom radu. Istražujući migracijske procese iz Krivoga Puta na područje Virovitice, zabilježilo se sjećanje na prve godine života u novom prostoru, te odnose između migratornog i domicilnog stanovništva. Stoga se dio rada odnosi na kulturne procese i translokalizme, točnije povezanost migranata i njihovih potomaka s mjestom porijekla. Prilikom razgovora napravljena je i fotodokumentacija stanja na terenu te su pregledani obiteljski albumi kazivača.

Podaci o migracijama s kraja 19. i početka 20. stoljeća dobiveni su tehnikama intervjua odnosno kroz životne priče (life stories) u lokalnim zajednicama. Dio istraživanja proveden je u Matičnom uredu u Virovitici gdje smo pregledale nekoliko knjiga rođenih i krštenih, te u Mjesnom uredu Suhopolje gdje smo pregledavale Indekse rođenih, knjigu vjenčanih parova - Vjenčanike, te Zavičajnik mjesta Rezovac. Također, koristile smo i internetske baze podataka, što je navedeno u popisu izvora.

\section{ODLAZAK ZBOG POSLA ILI TRBUVOM ZA KRUVOM}

$\mathrm{J}$ ednu od mnogih jedinstvenih migrantskih priča pronašle smo u kazivanju Vladimira Prpića (Podgorje), pripadnika druge generacije migranta ${ }^{8}$ : U Krivom Putu je bilo teško. Škrta zemlja a puno duša ... kod mog oca u Maticima bilo ih je 24 u kući, to je bila zadruga ... pazite, did Jura, od oca tata, pa did Marka, brat od dida Jure, i njihova dica, i opet njihova djeca (...) al oni su odma odlazli za poslom po vani kad su stasali za posao. I tu je bio kovać, i jedan kolar. I oni su se razišli 'r'uvom za kruvom. Onda je ostala kuća stara (...) sad je to ničije, ima tamo oko devet jutara zemlje, to su tamo dulibe i šume. Primarne gospodarske grane područja Krivoga Puta nisu bile dostatne za život, te su muškarci nalazili dodatne izvore prihoda. ${ }^{9}$

\footnotetext{
Šira geografska i kronološka analiza uvelike bi premašila opseg jednog članka.

Istraživanja je provela M. Rajković

Istraživanja je provela J. Jurković, dugogodišnja suradnica na navedenom projektu, vidi rad: Tradicijska prehrana kao prilog poznavanju primorsko-bunjevačkog identiteta. Senjski zbornik, (2004) 31:189-212.

6 Rezovačke Krčevine udaljene su 10 kilometara, a Podgorje 6 kilometara od Virovitice.

7 Pri tome su neke discipline neposredno zainteresirane za studij migracija, a druge tek posredno i djelomično. Među prvima su: geografija, demografija, antropologija, ekonomija, urbano i ruralno planiranje, te sociologija. U druge spadaju: povijest, politička i medicinska znanost (Mesić 2002:239). Autor ne navodi etnologiju.

8 Druga generacija migranata: izraz koji se odnosi na djecu migranata, u pravilu rođenu u mjestu doseljenja (usp. Heršak 1998:43).

9 Više o tradicijskom gospodarstvu vidi u prilogu M. Rajković, u nastavku ove monografije.
} 
Hrvatska je tradicionalno migracijska i iseljenička zemlja s povijesno promjenjivim modalitetima migracija, koji su bili prvenstveno pod utjecajem razlika između dosegnute razine društveno-gospodarskog razvitka naše zemlje i zemalja imigracije ili emigriranja stanovnika Hrvatske. Stoga je Hrvatska sa zemljama zapadne Europe i zemljama prekomorske imigracije imala jedan migracijski smjer - hrvatsko emigriranje (usp. Lajić 1998:7). Migracije s područja Krivoga Puta prate trendove migracija s područja ovih prostora (Dalmacije, središnje Hrvatske) (usp. Jonjić 1998: 5-9). Dakle, krajem 19. stoljeća i početkom 20. stoljeća najbrojnije migracije bile su u prekomorske zemlje (ponajviše u SAD i Kanadu). Drugi pravac, kojim se kretao manji broj migranata, činio je zemlje zapadne Europe (ponajviše Francusku, Belgiju, Švicarsku). Brojne migracije odvijale su se prema sjeveroistoku, u ostale dijelove Hrvatske, najčešće Slavoniju ${ }^{10}$, a zatim i dalje prema istoku, primjerice u Srbiju, Crnu Goru i Rumunjsku ${ }^{11}$.

Privlačni faktori za odlazak na sjeveroistočna područja, odnosno unutrašnjost matične zemlje, bila su područja bogata šumom, budući da su se i na području Krivoga Puta najviše bavili šumarstvom. Kroz kazivanja doznale smo da u najvećem broju slučaja prilikom odlaska migranti nisu imali točno odredište; naime bilo je svejedno hoće li otići u Slavoniju, Vojvodinu, Srbiju ili Rumunjsku. Oni su išli za šumom, gdje se šuma ruši. Recimo moj otac i njiovi. Stric Stipa je išo i u Karlovac, on je imo četri para konja pa je kirijo, to izvaža. On je bio najstariji, imao je i kapitala više, pa je svoju braću suzdržava ${ }^{12}$. Unatoč dislociranosti obitelji, kazivači su isticali da su se međusobno pomagali ${ }^{13}$.

Drvosječe, odnosno šumski radnici, tražili su privremeni posao i zadržali se ondje dok je trajala radna sezona. Prema kazivanjima odlasci na područja Virovitice sežu s kraja 19. stoljeća, a odlazak se prenosio s generacije na generaciju. Tako je bilo slučajeva kada su i dječaci bili uključivani: Moj otac je sa svojom starijom braćom dolazio tu u kasnu jesen, mogli su rušit tek kad se smrzlo, jer tu su bile baruštine, močvarno, jeli nije bilo meliorizirano. Bilo je hladno, a čujte nisu pitali, napravili su si baraku u šumi, ne samo oni $i$ drugi ljudi ... otac koji bi sad imao 105 godina, on je tu većs 9 godina dolazio, on im je kuva i pomaga nosit hranu. I njihov tata je tu prije dolazio radit ${ }^{14}$. Nakon što je kroz jesen i prvi dio zime sezona prošla, zaradilo se nešto novaca i vraćalo kući.

Prema kazivanjima svih kazivača ekonomski faktori bili su najveći uzroci odlaska na privremene radove. Krajem 19. stoljeća i početkom 20. stoljeća migranti su bili pretežito mladi muškarci, što je vidljivo i iz arhivskih podataka (vidi tablice 1 i 2). U ovom razdoblju, prevladavali su aktivni migranti ${ }^{15}$, dakle osobe koje su same istraživale moguća odredišta za odlazak na rad.

Privremene migracije ponavljale su se tijekom više godina. Vremenski period njihova ponavljanja ovisio je od osobe do osobe. Stoga su odlasci na područje okolice Virovitice rezultirali da se početkom 20. stoljeća Krivopućani ondje počnu trajno naseljavati: Jedni su dolazili i odlazili, a puno ih je tu došlo na kratko $i$ nisu se više ni vraćali ${ }^{16}$. U početku su se pojedini mladići priženili djevojkama iz virovitičke okolice. $S$ vremenom su umjesto novčane naknade šumski radnici mogli dobiti iskrčeno zemljište, što su pojedinci rado prihvaćali i time se velik dio privremenih migracija pretvarao u trajne migracije. Tijekom privremenih migracija migranti su imali na području Krivoga Puta djevojke ili supruge te je ovo dobivanje zemljišta rezultiralo i njihovim postupnim dolaskom. Dakle, uslijedile su bračne i lančane migracije, te su osim članova bliže ili daljnje obitelji dolazili i prijatelji te susjedi. Oni su jedan drugog upućivali, tu ćeš se moć zaposlit ... tu su bile dvije pilane ... prije je bila jedna velika pilana ${ }^{17}$. Sličan je primjer zabilježen i u

10 Pojam Slavonija ne poklapa se s današnjim ustrojem RH i regijom Slavonijom. Kazivači su pod Slavonijom smatrali cijelo područje središnje i istočne Hrvatske, od Karlovca pa do istočnih granica.

11 Više o migracijskim mobilnostima Krivopućana vidi u radu M. Rajković, u ovoj monografiji.

12 Vladimir Prpić Matić, Jukin, Podgorje, Virovitica.

13 Detaljnije u ovom prilogu u odlomku o komunikacijama i vezama s Krivim Putem.

14 Vladimir Prpić Matići, Jukini, Podgorje, Virovitica

15 Aktivni migrant, od. egl. active migrant; dosl. znači “djelatan migrant” (Heršak 1998:4).

16 Vladimir Prpić Matići, Jukini, Podgorje, Virovitica

17 Ibid. 
obitelji Filipović: Tata je htio isto u Ameriku, al je stric već tu radio kao željezničar, kao skretničar i onda on ajde u Slavoniju, u Slavoniji ima zemlje ${ }^{18}$.

Osim ostanaka šumskih radnika često su preseljenja u Viroviticu bila planirana preseljenja kojima je prethodila najčešće privremena transkontinentalna migracija radi stjecanja početnog kapitala. Baka je bila 1873. godište ... did je u Ameriku išo prije Prvog svjetskog rata, i bio je tamo 12 godina, još je bio kad se kanal Paname završavao, i pričao je kako je i tamo bilo teško živjet. A neki su se ljudi snašli. Tamo je radio u rudniku (...), a višse ih je odlazilo, jedan drugog su povezivali, bio je i u Kanadi i u Ameriki i u Južnoj Ameriki. Djed i baka su tu došli 1924., a tata je bio rođen $1912^{19}$.

Najveći val migracija završen je tridesetih godina 20. stoljeća, a tek pojedinačni primjeri zabilježeni su i kasnije. Na migracije poslije Drugoga svjetskog rata osim gospodarskih faktora utjecali su politički razlozi, kao što je vidljivo u idućoj naraciji: Djed je bio kovač u Krivom Putu. Moj otac je iz Katića a mater mi je iz Lukići... otac je tu došo 1950. On se od 1945. sakrivo zato što je pobjego iz kolone. Moj djed je bio ubijen, spaljen u Drugom svjetskom ratu (...) oca je baka šest mjeseci skrivala u sjenu, nije poslije znao ni hodat, imao je 24 godine. Onda su jošživjeli u zadrugi i novac je zajedno bio i moro je uvjek tražit novac, i za cigarete. Ja sam već bio na putu. Ništa nije sam mogao i već mu je dosta bilo svega, i to je bio teško. A i bio je zapisan da je bio u neprijateljskoj vojsci, to je i mene pratilo. I meni je pisalo u vojnoj knjižici sin ustaše i cjelo vrijeme sam moro bit na terenu. I tak je moj stari uzeo onu žagu (pilu/op.a.), drveni kofer, ženu za ruku, moju mater ja sam već bio u trbuhu i došo u Podgorje odnosno tada Kozju Glavu ${ }^{20}$.

\subsection{SJEĆANJA NA SELIDBE}

$\mathrm{M}$

igracija nije samo čin preseljenja čovjeka iz jednog u drugo prebivalište. To je proces u kojem je čin preseljenja samo završni rezultat. Migrativni proces nastaje onoga trenutka kad čovjek (potencijalni migrant), nezadovoljan postojećim, počne razmišljati o odlasku iz postojbine. No migracije kao proces mogu se konceptualizirati i u smislu serije faza ponašanja (usp. Mesić, 2002:249). Standing razlikuje sedam (analitičkih) dinstinktivnih trenutaka u kojima se može naći svaki pojedinac: 1. bez pomisli na migraciju; 2. pomisao na migraciju, ali odbačena; 3 . planirana migracija, ali vrijeme i/ili odredište nesigurno; 4. migracija u tijeku; 5. migracija završena; 6. migracija provedena i ponovljena; 7. migracija provedena, povratak u područje porijekla ili mjesto prethodnog prebivanja (usp. Ibid. prema Stading 1984:57) čija će se zastupljenost nastojati prikazati kroz rad. Osoba najčešće intuitivno, stavlja na vagu dobre (faktori ostanka) i loše (selidbeni motivi) strane organizacije svoga života. To je osnova teorije "push" i "pull” faktora.

Mada su mnogi iselili iz Krivoga Puta, neki su ipak ostali. Stoga se u ovom radu postavlja i pitanje zašto, primjerice, u situacijama masovnih migracija neke grupe ili osobe nopće na razmatraju migracije kao moguću орсіju (Mesić 2002:249). Standingova shema istodobno sugerira da migracijske studije u kompleksu društvenog procesa uključuju i povratak ${ }^{21}$, pa i objašnjenje nepokretnosti, nemigratornosti. Kroz razgovore s Krivopućanima iz Krivoga Puta saznaje se da nisu selili imućniji; primjerice kada bi bilo jedno muško dijete u obitelji, ono je ostajalo. Tako je primjerice Marko Pavelić Mijatina (Podbilo) istaknuo da on nikada nije odlazio niti na privremene radove jer za to nije imao potrebe. Drugi razlog bile su bogatije djevojke kojima su se mladići priženili. Od brojne djece ponekad bi samo jedno dijete ostalo s roditeljima. Razlog tome nije običajno pravo nasljeđivanja, da primjerice najstariji sin ostaje s obitelji ili pak najmlađi. Razlog zašto su svi iz obitelji odselili osim njega, Marko Tomljanović Rilac (Mrzli Dol) objasnio je: Brat (koji je otišao živjeti u Viroviticu/op.a.) je bio sposobniji. Imao je malo škole i nije volio radit, bio je najstariji oženio se i otišo. Bilo je nas pet braće i sestra. Trbuvom za kruvom kako se rě̌e, tu se oženio 1949. i 1950. je otišo. Dva

18 Ivan Filipović Vicinov, Virovitica.

19 Vladimir Prpić Matići, Jukini, Podgorje, Virovitica.

20 Podaci o kazivaču nalaze se u transkriptima.

21 Detaljnije vidi u odlomku Trajna vraćanja. 
brata su otišla u Zagreb i jedna sestra, jedan brat je umra. Prema navedenom zaključujemo da su ekonomski razlozi utjecali kako na odlazak tako i na ostanak.

Zanimalo nas je kako su selili, odnosno putovali Krivopućani, što su sve nosili sa sobom. Odgovor na to pitanje zrcali se u naraciji Vladimira Prpića (Podgorje): A čujte, onda je već bila pruga od Rijeke, to je bilo 20-ih. Isli su brodom za Rijeku, onda prugom, vlak je vozio. Jer je prije Prvog svjetskog rata Virovitica imala prugu za Budimpeštu. Prilikom odlaska migranti su nosili malo prtljage, uglavnom odjeću i sitnije predmete. Svi kazivači isticali su da ništa nisu niti imali. Draga Tomljanović Rilčeva (Mrzli Dol) dodala je: $A$ nije tog bilo puno za nosit, dva kofera, zeru robice one. Ma u dvi vreće stavili sve. Ko da je tog bilo ko danas... ja sam se udavala, niti sam štogod donila, niti našla (...) moj ćaća isto nije ima, sirotinja ja i on, odonda do danas ja mislem da sad živem u Ameriki. Bila sam gladna, gola, bosa, nisi ima na šta leć.

Premda kazivači nisu posebno isticali da čuvaju za uspomenu predmete iz Krivoga Puta, njihova sjećanja to potvrđuju: Imaju one gargeše što se vuna grabljala, pa je bila neka stupa, a što su oni onda, ne znam. Nije bilo namještaja ko danas. Neki stol smo dugo imali (...) od javora, a neka ploča osamdeset široka, al već se bio ucrvo pa smo ga bacili. Znali su stari ljudi pričat da je tolko stara, da su se na njemu u Krivom Putu 'ajduci kartali (smijeh/op.a.) ${ }^{22}$.

Unatoč tome što su trajne migracije bile planirane, nije zabilježen niti jedan slučaj da bi se prilikom odlaska iz Krivoga Puta prodavala nepokretna imovina i time imao početni kapital za život na području Virovitice. Razlog tome objasnio je Josip Prpić (Podgorje, treća generacija migranata): Zemlja nikad nije bila na cijeni, i oni su prve živjeli u zadrugi, i kad ti raširiš tu zadrugu imaš više nasljednika, puno. I kak ćeš ti sad tu zemlju podjelit? A i to je bilo tak malo i bez cjene da nije bilo ni interesa. Njihovi potomci rijetko su kada kasnije prodavali obiteljske nekretnine. Većina kazivača ističe da i danas imaju zemlju na području Krivoga Puta, ali tek pojedini pokrenuli su ostavinsku raspravu i podijelili imovinu ili je prodali. Od oca jedan brat je u Zagrebu on ima dva sina i jedan je otišo u Požegu, i sad njegovi potomci žive u Novoj Gradiški i Požegi. Al niko od njih se nije poslije interesiro da bi podjelili tu zemlju. Jedino od mog oca braća su se odrekla zemlje radi dječjeg doplatka, (...) moja majka je imala jednog brata ... znam da je mama rekla: Jure, prodaj ti tamo zemlju pa kolko dobiš, i znam da je on to prodo (...) a ovi drugi ne znam da je neko nešta prodo. Cujte niko više ni ne traži zemlju, to su se ljudi snašli, istaknuo je Vladimir Prpić. Poneki poput Josipa Pavelića Zozana (Krčevine, Virovitica) tek po pričama znaju da tamo imaju zemlje: I dan danas tamo ima zemlje, $i$ šma neka od bake al je to sve zapušteno.

\section{3. ŽIVOT U NOVOJ SREDINI}

$\mathrm{D}$ olazak u novu sredinu svakako nije bio lagan ni bez poteškoća. Naš kazivač, Josip Pavelić Zozan (Krčevine, Virovitica), objašnjava: Tamo je bila neimaština, glad, tu su se više naseljavali zbog zaposlenja. Slično pojašnjenje ponudio je i Vladimir Prpić (Podgorje, Virovitica): Nije da ja sad podcjenjivam, al znate onaj narod je dosta bio bistar. A znate što ga natjera? Bijeda. Onda čovjek razmišlja! A ovdje u Slavoniji je bilo dosta bogato i hranom, pa nisu razmišljali, nije narod nikud iša. Naseljavanje Primoraca na virovitičko područje usmjerilo se prema okolici samoga grada Virovitice, u danas prigradska naselja Krčevine (sl.1, 1a) i Podgorje ${ }^{23}$. Oba naselja prepoznaju se po doseljenicima iz Krivoga Puta na što upućuje i većinska populacija, ali i sami potomci migranata koji sebe prepoznaju samo u ova dva naselja.

22 Vladimir Prpić, Matići, Jukini, Podgorje, Virovitica.

23 Naše ipitivanje provedeno je samo u ova dva mjesta jer smo samo za njih dobili podatke da su naseljeni Krivopućanima. No, migranti su se naseljavali i u druga mjesta. Više o tome ukazuju podaci u knjigama vjenčanih (Vjenčanik knjiga 447) gdje su zabilježeni pojedinačni slučajevi ženidbe u mjesta izvan Podgorja i Krčevina, primjerice: Cabuna, Žubrica, Budanica, Jugovo Polje, Borovo. Također, jedan od sugovornika Dinko Filipović Vicinov prisjetio se: Dida i jedan brat su se doselili u Jugovo polje što potvrđuje pojedinačne slučajeve odlazaka izvan ova dva lokaliteta. Zbog opsežnosti takvog istraživanja ovim radom nismo obuhvatile i te slučajeve. 


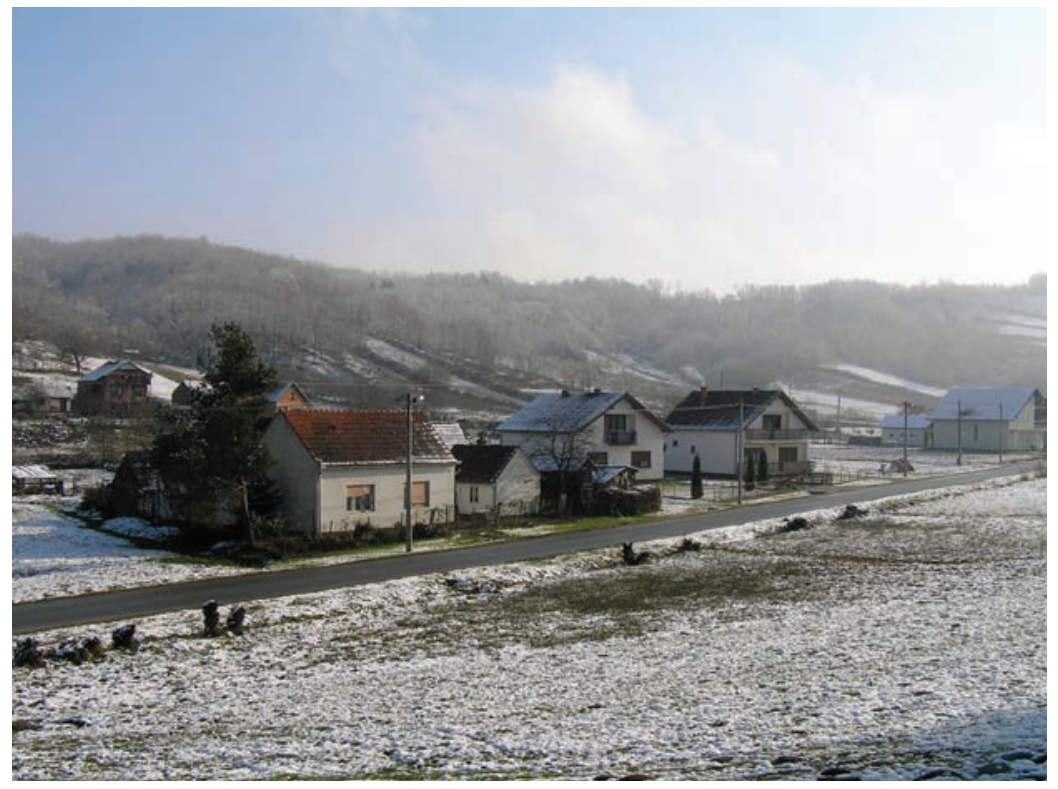

Slike 1: Detalj Rez̧ovačkih Krérvina; snimila M. Rajković, studeni 2006.

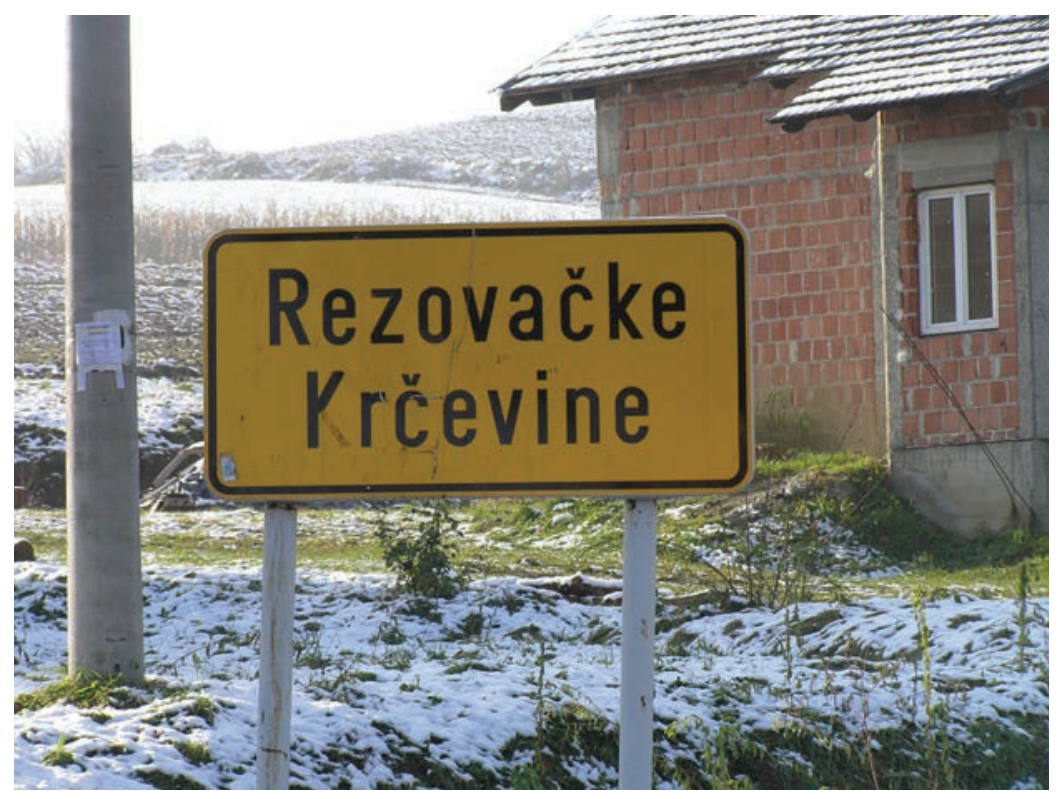

Slike 1a: Tabla snatpisom naselja; snimila M. Rajković, studeni 2006.

Podgorje, zvano Kozja Glava ${ }^{24}$, nastalo je krajem 19. stoljeća. Tada su zabilježeni prvi dolasci stanovnika iz okolice Senja i okolnoga primorskoga područja $a^{25}$.

24 Naselje Kozja Glava preimenovano je u Podgorje osamdesetih godina 20. stoljeća. Prvi spomen nalazi se u popisima stanovništva koje navodi povjesničar Rudolf Horvat u svoj knjizi iz prve polovine 20. stoljeća (obuhvaća razdoblje do 1934. godine). On navodi: Virovitica sa svojim predgradima i majurima (Antunovac, Brezik, Golo Brdo, Grabrik, Korija, Kozja Glava, Sveti Đurad, Sveti križ i Sveto Trojstvo) 31. prosinca 1880. brojila 840 kuća, u kojima se nalazilo 1278 kućanstava i 5586 žitelja, od toga 2735 muškaraca, a 2851 ženskog spola. (...) (Horvat, 2001: 104). Dalje u knjizi navodi za svako naselje broj kućanstava, pa tako za Kozju Glavu navodi da je 1890. imala 11 kuća i 43 žitelja (108 str.), 1900. 10 kuća i 70 žitelja (112 str.), zatim 1910. Kozja Glava je brojila 149 žitelja (119 str.), te 1931. 437 žitelja (Ibid. 128). Danas Podgorje ima oko 1000 stanovnika hrvatske nacionalnosti (usp. www.podgorje.net/povijestpodgorja.php )

25 Prema podacima iz knjige vjenčanih - Vjenčanika, doseljenici su bili iz naselja Krmopta, Alana, Melnice, Vratnika, Krivoga Puta, Stolca, Mrzloga Dola te Podbila. 
Naselje Krčevine nastalo je prvih desetljeća 20. stoljeća. Doseljenici su krčili šume za pilane te su dobivali zemlje kako bi se trajno naselili. Rezovačka Krčevina (odnosno Rezovačke Krčevine) iskazuje se kao naselje od 1931. godine (Korenčić, 1979: 712, 714). Ovo su potvrdili i naši sugovornici s virovitičkoga područja, tako Vladimir Pavelić Kuzman navodi: Kad su oni osnivali selo nije bilo prvi naziv da će biti Krčevine, Rezovačke Krčevine. Prvo su oni htjeli to selo nazvati Gornja Dubrava, da. Pa su onda na kraju sastali, pa né́emo tako, mi smo to došli, iskrčili, pa neka bude naša krčevina. I odustali od toga. A onda su još dali prilog uz to, jer je bilo uz Rezovac, jel' i eto to stoji do danas. A mi danas želimo taj prilog isključiti, da to budu samo Krčevine, i ništa više, bez Rezovac.

Stanovništvo se bavilo krčenjem šuma i radom u pilani, dok su se nakon Drugoga svjetskog rata bavili i vinogradarstvom ${ }^{26}$ i zemljoradnjom. Povjesničar Josip Adamček navodi: Šume su imale izuzetno značenje u životu svih stanovnika virovitičkoga vlastelinstva. U najstarijem popisu virovitičkoga vlastelinstva mnoge se od njih spominju kao dijelovi hatara pojedinih sela. Kmetovi su drvo iz tih šuma koristili kao gradu, za ogrijev $i$ mnoge druge potrebe. Žirom su se hranile svinje. Raskrčivanjem šuma i šikara seljaci su proširivali svoje poljoprivredne površine. Urbar iz 1756. unio je promjene u seljačko pravo korištenja šuma. Proglasio je da su šume vlasništvo zemaljske gospode i da ih seljaci mogu koristiti samo pod njihovom kontrolom (Adamček, 1986:165).

Iako su svi naši sugovornici isticali vlasnika šuma, gazdu Gutmanna, literatura ga ne svrstava u veleposjednike virovitičkoga područja. Transport drveta provodio se šumskom željeznicom iz bogatih staništa hrastovih šuma u Slavoniji i Podravini, rezultat potrebe za sirovinom tadašnje pilane i tvornice S. H. Gutmann u Belišću iz druge polovine 19. stoljeća (Horvat, 2002:34). S vremenom posao se proširio što je dalo temelje izgradnji šumsko javnih željeznica u narodu prepoznate kao "Gutmannove željeznice". Ovo bi moglo pojasniti zašto se naši sugovornici prisjećaju Gutmanna kao vlasnika željeznice. Tako se i Vladimir Prpić Matićin prisjeća: E, pa Gutmann taj, tu je imo tu pilanu. Ti Primorci dolazili su ovdje radit, to su ljudi čvrsti, što kažu od kamena. To je njima dobro došlo. Na primjer taj Drah i Gutmann, on je baš njima davo dobre uvjete $i$ kredite. To su se ljudi onda naseljavali. Vladimir Pavelić Kuzman je istaknuo: Taj Gutmann, on je vršio prijevoz, da ne bi ljudi vukli to sve na sebi ili kolima. On je sagradio uskotračnu prugu i to savremenu što se gradi u dva smjera da se nisu morali sudarati, e a gore su imali okretiste. To je bilo u ono vrijeme kad su oni najviše rušili šume, da tam negde od dvadestih do tridesetih godina. Kazivači s Krivoga Puta također su spominjali Gutmanna. Njega su ubili partizani, pojasnio je Ivan Tomljanović Rokin (Vrataruša).

Prvi migranti, pretežito mladi muškaraci, radili su po šumama i živjeli u istima u privremenim drvenim kolibama/barakama. O teškim uvjetima u Podgorju Vladimir Prpić rekao je: Ako biste gledali unazad 100 godina, na primjer po mom ocu, on je tu živio gdje je sad Lovište, mi smo to zvali prije sintarnica (...) mi smo to nazivali da izvinete vododerina, to se sa svih strana sljevala voda, ta ilovača, da nisi mogo ništa, ajoj, Bože sačuvaj! Tak da su moji odma pobjegli kad su mogli tu u ovaj kraj (danas žive u Podgorju/op. a.) tu je malo blaže. O lošim uvjetima stanovanja govori i činjenica da su djeca umirala: Dvi godine su bili u Krčevinama, onda su tu u Podgorju našli to malo. Ma to vam je znate kuće su bile šepave, ja sam se tu rodio i moj brat, on je bio 30to godište, dva brata su i umrla, rekao je Vladimir Prpić. Podatke o mrtvorođenoj djeci pronalazimo i u knjigama rođenih i krštenih (vidi tablicu br. 2).

U knjigama rođenih također saznajemo da su migranti stanovali na lokalitetima koja nisu imala adrese, odnosno umjesto naziva ulice i kućnog broja najčešće nalazimo: Sv. Juraj (vinogradi), Kozja Glava, Sipova Kosa, Polanec (šuma), Golo Brdo, Sv. Križ (usporedi tablicu br. 2) ${ }^{27}$.

Dolazak žena i djece, odnosno cijelih obitelji utjecao je na postupnu gradnju trajnije nastambe i obrađuju manje parcele zemlje. Time je za većinu migranata započeo proces "sjedilačkog načina stanova-

26 Tako se 1953. odvaja dio stanovništva i osniva naselje Rezovački Vinogradi koje broji 183 stanovnika (usp. Korenčić 1979:712)

27 Knjiga rođenih i krštenih br. 403 (od 1917. do 1922. godine), Matični ured Virovitica. 
nja”. Doseljeno stanovništvo je radilo na krčenju šuma, pilanama, a onda su imali zemljišta pa su se iza drugog rata bavili i zemljoradnjom, te vinogradarstvom. A i dosta je bila zamjena sokolnim stanovništvom, ovi su njima davali vino, a ovi preko brda njima žito 28.

Također pregledan je dio popisa Zavičajnika mjesta Rezovac, koji se nalazi u Općini Suhopolje. Ovaj popis sastavljen je na osnovu starih popisa Zavičajnika i listina domaćinstava koje su sastavljane povodom Općeg popisa pučanstva godine 1932. U Zavičajniku su navedeni podaci o imenu i prezimenu osobe, rođenje (mjesto, općina, srez, za rođene u inozemstvu-državu; dan, mjesec, godinu, spol), stališ (zanimanje), koliko je osoba bila odsutna (privremeno, trajno), smrt (dan, mjesec, godina), na temelju čega je osobi priznata zavičajnost, a postoji i rubrika za primjedbe. Iz Zavičajnika saznajemo da je 1933. godine bilo oko 1403 stanovnika ${ }^{29}$, od toga je 67 bilo rođenih u Krivome Putu (Veljun, Mrzli Dol, Krivi Put) krajem 19. i početkom 20. stoljeća. Dakle, ako znamo da su migracije bile dvadesetih godina i ovi podaci nam potvrđuju da se uglavnom selilo mlado radno sposobno stanovništvo koje je u Rezovcu formiralo obitelji, budući da se kao mjesto rođenja djeci uglavnom navodi Rezovac ili Virovitica (vidi tablicu br. 1). Prezimena su: Tomljanović, Prpić, Pavelić, Krmpotić, Šojat, Blažević, Burić i Rončević. I podaci iz Zavičajnika potvrđuju najčešća zanimanja: radnik i kućanica.

U listinama domaćinstava, odnosno popisu kućanstva za mjesto Rezovac (sastavljeno 22. studenoga 1936. godine) pronalazimo upisana kućanstva od broja 3 do 113. Svakom kućnom broju pridodani su članovi obitelji, no uočava se da je još uvijek velik broj obitelji krivoputskoga porijekla stanovao u kućama bez kućnoga broja.

\begin{tabular}{|c|c|c|c|c|}
\hline $\begin{array}{l}\text { Prezime + članovi } \\
\text { kućanstva }\end{array}$ & Mjesto rođenja & $\begin{array}{l}\text { Godina } \\
\text { rodenja }\end{array}$ & zanimanje & opaska \\
\hline $\begin{array}{r}\text { Prpić } \quad \text { otac }^{1} \\
\text { majka } \\
\text { sin } \\
\text { kći } \\
\text { sin }\end{array}$ & $\begin{array}{l}\text { Sv. Jelena (Krivi Put) } \\
\text { Krivi Put } \\
\text { Rezovačke Krčevine } \\
\qquad \begin{array}{l}\text { - II- } \\
\text { - II - }\end{array}\end{array}$ & $\begin{array}{l}1903 . \\
1906 . \\
1928 . \\
1930 . \\
1933 .\end{array}$ & $\begin{array}{l}\text { radnik } \\
\text { kućanica }\end{array}$ & $\begin{array}{l}\text { (nečitko) bio zavičajan u } \\
\text { općini Krivi Put }\end{array}$ \\
\hline $\begin{array}{cc}\text { Tomljanović } & \text { otac } \\
\text { sin } \\
\text { sin } \\
\text { sin } \\
\text { žena }\end{array}$ & $\begin{array}{l}\text { Krivi Put } \\
\text { Virovitica } \\
\text { Virovitica } \\
\text { Rezovačke Krčevine } \\
\text { - II- }\end{array}$ & $\begin{array}{l}1882 . \\
1919 . \\
1922 . \\
1929 . \\
1921 .\end{array}$ & $\begin{array}{l}\text { udovac, } \\
\text { ratar } \\
\text { neoženjen }\end{array}$ & \\
\hline 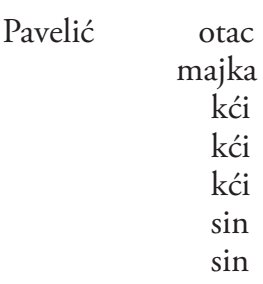 & $\begin{array}{l}\text { Mrzli Dol (Krivi Put) } \\
\text { Mrzli Dol ( - II - ) } \\
\text { Rezovac } \\
\text {-II- } \\
\text {-II- } \\
\text {-II- } \\
\text {-II- }\end{array}$ & $\begin{array}{l}1894 . \\
1898 . \\
1920 . \\
1922 . \\
1924 . \\
1925 . \\
1928 .\end{array}$ & ratar & $\begin{array}{l}\text { Do sad bio zavičajan u } \\
\text { općini Krivi Put, br. op. } \\
\text { 5094/39. }\end{array}$ \\
\hline
\end{tabular}

Bilješka uz tablicu

1 Umjesto imena odlučile smo navesti samo srodstvo.

28 Josip Prpić, Matići, Jukini, Podgorje, Virovitica.
29 Pri kraju popisa razlivena je tinta, pa je nečitko. 


\begin{tabular}{|c|c|c|c|c|c|}
\hline Pavelić & $\begin{array}{r}\text { otac } \\
\text { majka } \\
\text { sin } \\
\sin \\
\text { sin }\end{array}$ & $\begin{array}{lc}\text { Mrzli Dol } & \text { (Krivi Put) } \\
\text { Mrzli Dol } & (\text { - II - ) } \\
\text { Virovitica } & \\
\quad \text {-II- } & \\
\quad \text {-II- } & \end{array}$ & $\begin{array}{l}1892 . \\
1902 . \\
1924 . \\
1926 . \\
1927 .\end{array}$ & $\begin{array}{l}\text { radnik } \\
\text { kućanica }\end{array}$ & $\begin{array}{l}\text { Do sad bio zavičajan u } \\
\text { općini Krivi Put, br. op. } \\
6352 / 1939 .\end{array}$ \\
\hline Marinčić & $\begin{array}{c}\text { otac } \\
\text { majka } \\
\text { sin } \\
\text { sin } \\
\text { kći } \\
\text { sin }\end{array}$ & $\begin{array}{l}\text { Virovitica } \\
\text { Krivi Put } \\
\text { Rezovac } \\
\text { Bazije } \\
\quad \text { - II - } \\
\text { Virovitica }\end{array}$ & $\begin{array}{l}1888 . \\
1906 . \\
1916 . \\
1923 . \\
1929 . \\
1933 .\end{array}$ & $\begin{array}{l}\text { čuvar pruge } \\
\text { bravar }\end{array}$ & \\
\hline Pavelić & $\begin{array}{r}\text { otac } \\
\text { majka } \\
\text { sin }\end{array}$ & $\begin{array}{l}\text { Mrzli Dol (Krivi Put) } \\
\text { Lukač } \\
\text { Rezovac }\end{array}$ & $\begin{array}{l}1903 . \\
1909 . \\
1930 .\end{array}$ & $\begin{array}{l}\text { radnik } \\
\text { kućanica }\end{array}$ & Ovdje trajno od 1920. \\
\hline $\begin{array}{l}\text { Karas } \\
\text { dj. Blažević }\end{array}$ & $\begin{array}{l}\text { otac } \\
\text { žena }\end{array}$ & $\begin{array}{l}\text { P. Sesvete } \\
\text { Krivi Put }\end{array}$ & $\begin{array}{l}1901 . \\
1894 .\end{array}$ & $\begin{array}{l}\text { radnik } \\
\text { kućanica }\end{array}$ & \\
\hline Vertike & $\begin{array}{r}\text { otac } \\
\text { majka } \\
\text { sin }\end{array}$ & $\begin{array}{l}\text { Budakovac } \\
\text { Krivi Put } \\
\text { Rezovačke Krčevine }\end{array}$ & $\begin{array}{l}1914 \\
1918 \\
1938\end{array}$ & $\begin{array}{l}\text { radnik } \\
\text { kućanica }\end{array}$ & $\begin{array}{l}\text { Stanuju u Rezovcu od } \\
\text { 1927. godine. }\end{array}$ \\
\hline
\end{tabular}

Tablica br. 1. Prikaz članova kućanstva. ${ }^{30}$ Podaci preuzeti iz Zavičajnika mjesta Rezovac (sastavlien na osnoun starih popisa zavičajnika i listina domaćinstava koje su sastavljane povodom Općeg popisa stanovnika 1932. godine). Općina Suhopolje.

\subsection{SOCIJALNO UZLAZNA DRUŠTVENA POKRETLJIVOST DRUGE I TREĆE GENERACIJE MIGRANATA}

$\mathrm{N}_{\mathrm{d}}^{\mathrm{a}}$ akon teških životnih uvjeta migranata, u drugoj generaciji migranata uočavamo uzlaznu vertikalnu društvenu pokretljivost. Naime, generalno gledajući prema načinu života migranti i njihovi potomci manje se razlikuju od domicilnog stanovništva. Pojedinci postupno stječu materijalno blagostanje, ali i socijalni kapital. Pomak se mjeri prema polazištu same osobe, odnosno prema stanju koje je naslijedila od svoje obitelji (dakle pomak u položaju sina prema ocu ili djedu) (usp. Heršak, 1998: 43; Bolaffi et al. 255-259). Nakon 40-ih godina 20. stoljeća u matičnim se knjigama kao mjesto stanovanja češće navodi adresa koja uključuje naziv ulice i kućni broj i uočavaju se promjene u zanimanjima ${ }^{31}$.

Danas stanovnici Krčevina i Podgorja uglavnom rade u tvrtkama u Virovitici: više nema Gutmanna već DIP, ciglana $i$ te firme ${ }^{32}$. Poljoprivreda je ponekima dopunska djelatnost, uglavnom uzgajaju povrće za osobne potrebe: Nemreš jer se spušta divljač, vidite dokle je šuma došla, a prije se to sve radilo, a sad neće niko radit ne isplati se, ja sam imo tu komad kukuruza i pola je divljač pojela, a niko neće platit stetu, imaju ta privatna lovišta, prije su bar plaćali ${ }^{33}$.

\footnotetext{
30 Ključni pojmovi po kojima su vađeni podaci su prezimena i mjesto rođenja s područja Krivoga Puta. U tablici je prikazano nekoliko primjera kućanstva, budući da bi prikaz svih premašio okvire ovog rada.

31 Detaljnija analiza ostaje temom nekog drugog rada.

32 Vladimir Prpić, Matići, Jukini, Podgorje, Virovitica.

33 Josip Pavelić Zozan, Krčevine, Virovitica.
} 
Podgorje i Krčevine kao prigradska naselja pružaju mladim obiteljima ugodan život koji uključuje dobru infrastrukturu i dobru prometnu povezanost s gradom. Jel smo atrakcija što smo blizu grada, al opet je mir, imaju ceste i sve a opet je priroda imaju ti vinogradi, poljoprivredni dio, plodna je zemlja ${ }^{34}$.

No i danas ima primjera iseljavanja u druge države, kao u obitelji Josipa Pavelića Zozana: Naša čerka se udala u Austriju i čak je i državljanstvo uzela, dosta i van ostali odlaze, jer tu nema posla.

\subsection{OBRAZOVANJE}

$\mathrm{K}^{2}$ azivači navode da su mnogi migranti bili nepismeni: Dida je bio poštar, i tamo je nosio poštu, dosta je ovako bio načitan. On je čito pisma ovako nekima koji su bili nepismeni ${ }^{35}$. Velik broj djece nije išao u školu, unatoč tome što je prva osnovna škola u Krivome Putu otvorena 1846. godine (usp. Raguž, 1999:344). Tijekom 19. i 20. stoljeća na području Krivoga Puta ${ }^{36}$ djelovalo je šest pučkih škola: Krivi Put, Alan, Vrataruša, Podbilo, Mrzli Dol i Veljun (Ibid. 343). Prema knjigama rođenih doznale smo kako su muškarci bili klasificirani kao radnici, šumski radnici, poljodjelci odnosno ratari, mlinari, zidari, činovnici i lugari (vidi tablice 1 i 2). Kazivači su isticali kako je najveći broj muškaraca izvore prihoda stjecao radeći kao šumski radnici. Na drugome mjestu zanimanja je ratarstvo odnosno poljodjelstvo, dok su ostala zanimanja zastupljena mjestimično. $U$ istim tablicama vidljivo je da se ženama nije navodilo zanimanje budući da su bile u većini slučajeva domaćice, odnosno kućanice. Tek dva primjera navode žensko zanimanje služavka, s opaskom da su majke rodile nezakonito dijete odnosno djeca su upisana bez očeva prezimena i zaposlenja (usp. tablicu br. 2). Naime, velik broj djevojaka nakon izvanbračne trudnoće odlazio je iz Krivoga Puta u druge krajeve rodbini ili poznanicima, budući da je ista sramota bila i za djevojku i njenu obitelj ${ }^{37}$.

Migranti su isticali da je već u drugoj generaciji migranata bilo i osoba na visokim funkcijama. Moj ujak sad bi imo 92 godine išo je u Viroviticu u gimnaziju, i mleko bi nosio, a završio je za komercijalnog direktora $^{38}$. O važnosti školovanja govori i činjenica da su se neki migranti naknadno selili radi blizine škola. Borili su se kolko su mogli, recimo imamo tu kumu (...) njih je bilo dvi kćeri i tri muška, i dva su inžinjera, ona je šumarsku školu završla, jedan je ugostitelj, a roditelji su nepismeni. Bili su u Cabuni, a posle su tu kuću napravili ... veli ona: Kume moj, doću ti ja u Podgorje kuću napravit tamo je blizu škola da ja mogu decu odskolat ${ }^{39}$.

Kazivači su isticali važnost školovanja, što je vidljivo i na navedenom primjeru: Znate što, čovjeka natjera um. Onda on proradi kad se treba borit za život, školovat se. Il onaj kad ode iz Hercegovine u Zagreb u školu, kažu mu nemoj se vraćat ak ne završiš, al onaj u Zagrebu (stanka/op.a.), imam ja take rodake, baš od Primoraca, deset godina i nisu ništa završili, jer je imalo sve podobnosti (smijeh/op.a. $)^{40}$

Po dolasku migranata, osnovno školovanje za djecu s područja Krčevina i Podgorja bilo je organizirano u školama u gradu Virovitici. Tek od sredine osamdesetih godina u Rezovačkim Krčevinama i Podgorju izgrađene su osnovne škole (usp. Pavlica 1986, 470-471). Dok u Podgorju danas nema područne škole, u Područnoj školi Rezovačke Krčevine (spada pod Osnovnu školu „Ivana Brlić Mažuranić“, Virovitica) danas nastavu pohađaju učenici od prvog do četvrtog razreda i to u miješanim razrednim odjeljenjima.

\footnotetext{
34 Josip Prpić, Matići, Jukini, Podgorje, Virovitica.

35 Ibid.

36 Područje Krivi Put obuhvaća naselja: Alan, Vratarušu, Podbilo, Klaričevac, Krivi Put, Mrzli Dol. Detaljnije vidi u radu Blaženke Ljubović u ovoj monografiji.

37 Detaljnije o svadbenim običajima bit će objavljeno u drugom svesku Monografije o Krivome Putu.

38 Vladimir Prpić, Matići, Jukini, Podgorje, Virovitica.

39 Ibid.

40 Ibid.
} 


\subsection{GRANICE DRUŠTVENIH ZAJEDNICA NA PRIMJERU SKLAPANJA BRAKOVA I KUMSTVA}

Dosebno su nas zanimale granice društvenih zajednica, u ovom slučaju domicilog i migratornog sta1 novništva. To smo nastojale saznati pomoću odredivanja komunikacijskog lanca koji se uspostavljao ženidbama $i$ kumstvima između doseljenog i starosjedilačkog stanovništva (usp. Čapo, 1988: 13).

Najviše podataka o ovoj temi prikupljeno je u Indeksima rođenih (Mjesni ured Suhopolje) i knjigama rođenih i krštenih (Matični ured Virovitica) gdje je pregledano nekoliko knjiga: knjiga pod brojem 403 (od 1917. do 1922. godine) te 404 i 405 (od 1922. do 1931. godine) (sl. 2) ${ }^{41}$. U matičnim knjigama saznajemo podatke o datumu, mjesecu i godini rođenja, zatim o datumu krštenja i o imenu duhovnog pomoćnika (osobe koja je vršila obred krštenja). Također, navedeni su podaci je li dijete zakonito ili ne te imena i prezimena roditelja, njihov stališ (zanimanje), vjera (zabilježeno je da su svi rimokatolici) i mjesto stanovanja (adresa i kućni broj). Zatim slijede podaci o krsnim kumovima, njihova imena i prezimena, stališ i vjera. Posljednju rubriku čini opaska koja je naknadno upisana, a najčešće je navedeno za koga se osoba udala/oženila, kada i gdje, te gdje je i kada umrla.

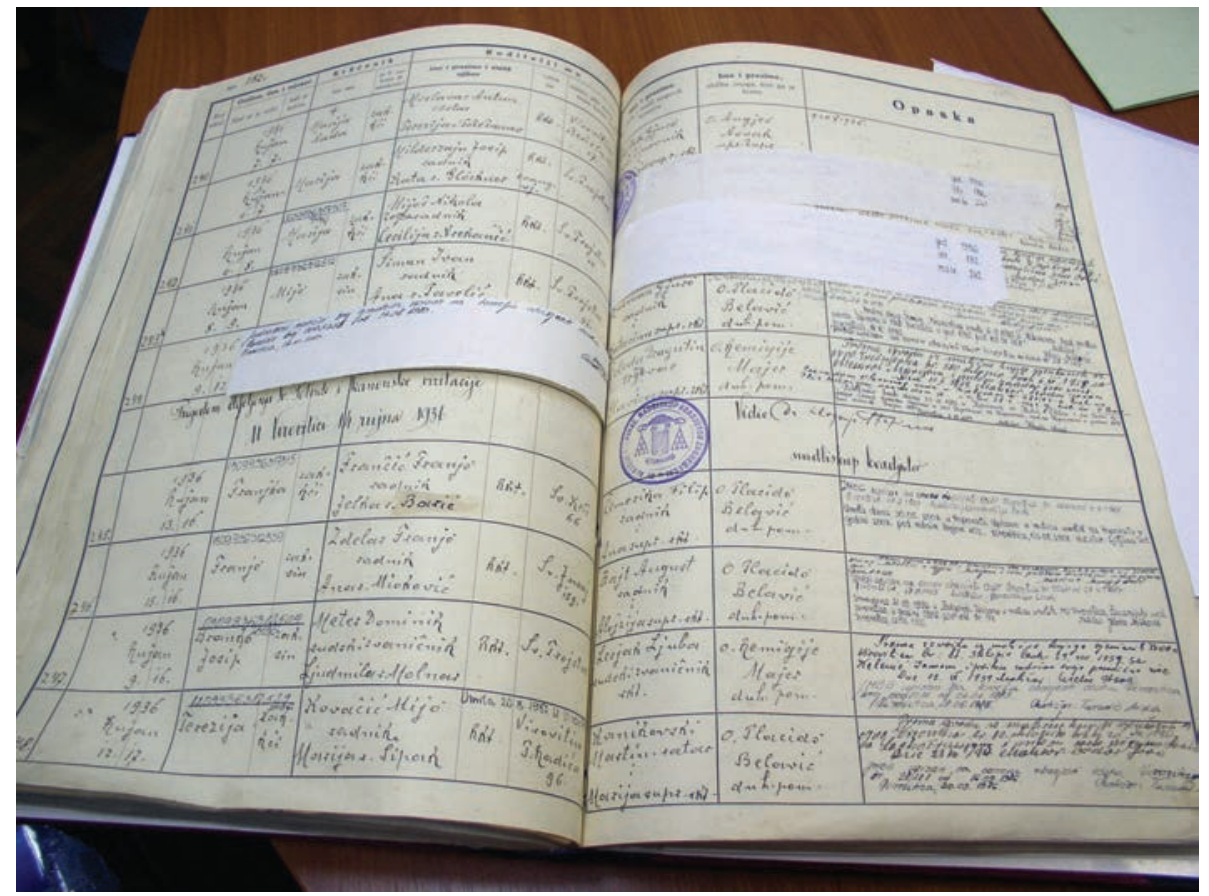

Slika 2: Stranica iz knjige rodenih i kerštenih. Matični ured Virovitica; snimila M. Rajković, studeni 2006. godine.

Iz navedenoga saznajemo da su majka i otac uglavnom bili Krivopućani, kao i kumovi. Kroz knjige rođenih može se pratiti kako su tekli procesi asimilacije na primjeru sklapanja bračnih i kumovskih veza, kako sa stanovništvom krivoputskoga porijekla tako $s$ domorodačkim virovitičkim stanovništvom ili $s$ ostalim etničkim skupinama na ovome području. Naime, iz mnogobrojne etnološke literature saznajemo da egzogamne bračne veze pospješuju procese asimilacije, te da djeca iz miješanih brakova u principu brže usvajaju kulturne obrasce dominantnog stanovništva.

U razdoblju od 1908. do 1925. godine u Rezovcu je rođeno jedanaestero djece čiji su roditelji Krivopućani. U razdoblju od 1926. do 1934. rođeno je 45 djece čiji su roditelji Krivopućani ${ }^{42}$. Pregledan je i Vjenčanik 1904.-1923. (knjiga 446) i Vjenčanik 1923.-1939. (knjiga 447). Podaci iz knjiga vjenčanih

41 Napisane su u Uredu rimokatoličke župe sv. Roka u Virovitici. Danas se čuvaju u Matičnom uredu Virovitici.

42 U razdoblju od 1935. do 1945. godine broj djece raste. Daljnja analiza premašila bi okvire ovoga rada. 
ukazuju na mjesto rođenja, mjesto stanovanja, imena kumova i drugo. Iz njih također saznajemo koliki je omjer ednogamnih i egzogamnih bračnih veza, odnosno koliko je doseljena skupina bila zatvorena ili otvorena prema domaćem stanovništvu, kao i odnos domaćeg stanovništva u pogledu istoga (sl.3).

Tablice s prikazom djece čiji su roditelji primorski Bunjevci. Kao pretpostavku da su roditelji Krivopućani također je uzimano krivoputsko prezime: Tomljanović, Blažević, Prpić, Rončević, Pavelić, Krmpotić.

\begin{tabular}{|c|c|c|c|c|c|c|c|}
\hline $\begin{array}{l}\text { Godina } \\
\text { rođenja }\end{array}$ & $\begin{array}{l}\text { Mjesto } \\
\text { rođenja }\end{array}$ & Prezime & $\begin{array}{l}\text { Djevojačko } \\
\text { prezime } \\
\text { majke }\end{array}$ & $\begin{array}{l}\text { zanimanje } \\
\text { majke }\end{array}$ & zanimanje oca & $\begin{array}{l}\text { Kumovi } \\
\text { (prezimena, } \\
\text { zanimanja) }\end{array}$ & brak \\
\hline 1919. & $\begin{array}{l}\text { Sv.Juraj, } \\
\text { vinogradi }\end{array}$ & Tomljanović & Blažević & 1 & zidar & $\begin{array}{l}\text { P. - nečitko } \\
\text { Z. - / }\end{array}$ & 1 \\
\hline 1919. & Polanec, šuma & Prpić & 1 & 1 & šumski radnik & Pavelić, trgovac ${ }^{1}$ & 1 \\
\hline 1919. & $\begin{array}{l}\text { Antunovac } \\
+ \text { kućni broj }\end{array}$ & Pavelić & Prpić & 1 & činovnik & $\begin{array}{l}\text { Prpić, šumski } \\
\text { poslovođa }\end{array}$ & 1 \\
\hline 1920. & $\begin{array}{l}\text { Sv.Juraj, } \\
\text { vinogradi }\end{array}$ & Tomljanović & I & 1 & mlinar & $\begin{array}{l}\text { Tomljanović } \\
\text { zidar }\end{array}$ & $\begin{array}{l}\text { s Vojković, } \\
\text { iz Virovitice }\end{array}$ \\
\hline 1920. & Sv.Juraj & Prpić & Krmpotić & radnica & radnik & Blažević & 1 \\
\hline 1921. & Sv.Juraj & Tomljanović & Markova $^{2}$ & 1 & poljodjelac & Prpić & 1 \\
\hline 1921. & $\begin{array}{l}\text { Kozja Glava } \\
\text { (mrtvorođeno } \\
\text { dijete) }\end{array}$ & Prpić & Blažević & 1 & ratar & 1 & \\
\hline 1921. & Sv.Juraj & Krmpotić & Sančak & 1 & zidar & Zvonin, ratar & $\begin{array}{l}\mathrm{s} \text { Turk u } \\
\text { Zagrebu }\end{array}$ \\
\hline 1921. & Sv.Juraj & Prpić & Rončević & 1 & radnik & Prpić, / & 1 \\
\hline 1921. & Sv.Juraj & Prpić & Krmpotić & 1 & ratar & Galetić, ratar & 1 \\
\hline 1922. & Sipova Kosa & Prpić & Prpić & 1 & šumski radnik & Pavelić, trgovac & 1 \\
\hline 1922. & Sv.Juraj & Tomljanović & Blažević & 1 & radnik & $\begin{array}{l}\text { Horvat, } \\
\text { vinogradar }\end{array}$ & $\begin{array}{l}\text { u Virovitici s } \\
\text { Violetinović }\end{array}$ \\
\hline 1922. & Sv.Juraj & Prpić & Prpić & 1 & ratar & Prpić, opančar & nečitko \\
\hline 1922. & Sv.Juraj & Tomljanović & Šolić & 1 & ratar & Prpić & $\begin{array}{l}\text { u Zagrebu } \\
\text { s osobom iz } \\
\text { Draganića }\end{array}$ \\
\hline 1922. & $\begin{array}{l}\text { Virovitica, } \\
\text { ulica + k.br. }\end{array}$ & Prpić & Pavelić & 1 & šumski radnik & Prpić, trgovac & 1 \\
\hline 1922. & Sv.Juraj & Prpić & Prpić & 1 & šumski radnik & $\begin{array}{l}\text { Tomljanović, } \\
\text { trgovac }\end{array}$ & 1 \\
\hline 1922. & Sv.Juraj & Pavelić & Prpić & I & radnik & Bošnjak, radnik & $\begin{array}{l}s \\
\text { Tomljanović }\end{array}$ \\
\hline 1922. & Golo Brdo & Prpić & Blažević & 1 & lugar & Matizalem, ratar & 1 \\
\hline 1922. & $\begin{array}{l}\text { Virovitička } \\
\text { župna bolnica }\end{array}$ & $\begin{array}{l}\text { (nezakonito } \\
\text { dijete) }\end{array}$ & Pavelić & služavka & 1 & Pavelić, trgovac & Zagreb \\
\hline 1922. & $\begin{array}{l}\text { Virovitica, } \\
\text { ulica+k.br. } \\
\text { (blizanci) }\end{array}$ & Prpić & Vlašimsky & 1 & trgovac & Bogardi & 1 \\
\hline 1922. & Golo Brdo & $\check{S}_{\mathrm{ojat}}{ }^{3}$ & Prpić & 1 & ratar & Ištvanović,ratar & 1 \\
\hline
\end{tabular}

\section{Bilješke uz tablicu}

1 Pod kumovi naveden je bračni par, a zanimanje se gotovo uvijek navodi samo za muškarca. Ako su navedena dva prezimena, primjerice Tomljanović/Prpić drugo prezime je bilo djevojačko prezime kume.

2 Markova je najvjerojatnije bio obiteljski nadimak, prezime nije navedeno.

3 Opaska: vjenčani u Krivome Putu. 


\begin{tabular}{|c|c|c|c|c|c|c|c|}
\hline 1922. & Kozja Glava & Prpić & Krmpotić & I & ratar & $\begin{array}{l}\text { Tomljanović, } \\
\text { šumski radnik }\end{array}$ & I \\
\hline 1922. & Sv. Juraj & Tomljanović & Tomljanović & & zidar & $\begin{array}{l}\text { Tomljanović, } \\
\text { mlinar }\end{array}$ & I \\
\hline 1923. & Sv. Križ & Prpić ${ }^{4}$ & Prpić & 1 & tesar & Virág, ratar & I \\
\hline 1923. & 1 & Prpić & Pavelić & 1 & opančar & Katalenić, ratar & 1 \\
\hline 1923. & Sv. Križ & Prpić & Krmpotić & l & $\begin{array}{l}\text { šumski } \\
\text { nadglednik }\end{array}$ & Cindrić, / & l \\
\hline 1923. & $\begin{array}{l}\text { Virovitička } \\
\text { župna bolnica }\end{array}$ & $\begin{array}{l}\text { (nezakonito } \\
\text { dijete) }\end{array}$ & Prpić & služavka & 1 & Karmalić & I \\
\hline 1923. & Sv. Juraj & Tomljanović & Škrget & & radnik & Harastijan, radnik & \\
\hline 1923. & $\begin{array}{l}\text { nejasno } \\
\text { (blizanke) }\end{array}$ & Rončević & Prpić & & radnik & Škrget & \\
\hline 1923. & Sv. Juraj & Prpić & Prpić & & ratar & $\begin{array}{l}\text { Zver/dj.Prpić, } \\
\text { radnik }\end{array}$ & \\
\hline 1923. & nejasno & Prpić & Pavelić & & šumski radnik & Prpić, učiteljica & $\begin{array}{l}\text { Brak u } \\
\text { Varaždinu }\end{array}$ \\
\hline 1923. & $\begin{array}{l}\text { Virovitica, } \\
\text { ulica + k. br }\end{array}$ & Prpić & Vlašimsky & & trgovac & $\begin{array}{l}\text { Tomljanovićl } \\
\text { dj.Prpić, } \\
\text { radnik }\end{array}$ & \\
\hline 1923. & Kozja Glava & Tomljanović & Prpić & & radnik & $\begin{array}{l}\text { Prpićl } \\
\text { dj.Krmpotić, ratar }\end{array}$ & \\
\hline 1923. & Kozja Glava & Prpić & Rončević & & pisar & $\begin{array}{l}\text { Tomljanović, } \\
\text { radnik }\end{array}$ & \\
\hline 1923. & Kozja Glava & Pavelić & Prpić & & radnik & Prpić, radnik & \\
\hline
\end{tabular}

Bilješke uz tablicu (nastavak)

4 Opaska: vjenčani u Krivome Putu 1921. godine.

Tablica br. 2. Prikaz rodenih i krštenih. Podaci preuzeti iz knjiga rodenih i kerstenih br. 403 (od 1917. do 1922. godine), knjiga br. 404 (rodeni u 1923. godini) ${ }^{43}$. Maticni ureda Virovitica.

Kazivači iz Krčevina i Podgorja kazivali su da se velik broj pripadnika prve generacije migranata oženio/priženio domaćim djevojkama ${ }^{44}$. No ubrzo i to u najvećem broju slučajeva mladići su dovodili djevojke, odnosno već žene budući da su se vjenčali u Krivom Putu, iz Krivog Puta ili njegove okolice. Matične knjige pokazuju da su se u razdoblju između 20-tih i 30-tih godina 20. stoljeća ponajviše ženili među sobom (vidi tablice 1 i 2). Tako je primjerice zabilježeno da se baka prezivala djevojački Prpić, pa se udala za Tomljanovića, a njezina kći opet za Prpića. Pregledavanjem vjenčanih knjiga (do 1940-ih godina) također se uočava najviše brakova između Krivopućana ${ }^{45}$. Danas kazivači govore: Al nije se to prije tak gledalo, recimo moja supruga je Madarica, a čujte kad se zaljubite ${ }^{46}$.

$\mathrm{Na}$ pitanje kako se i koga odabiralo za vjenčanoga ili krsnog kuma kazivači su odgovarali da se biralo nekoga simpatičnog, prijatelja, susjeda, ko kog hoće ${ }^{47}$. Ako usporedimo podatke iz matičnih knjiga uočavamo da su se u razdoblju između 20-ih i 30-ih godina 20. stoljeća kumstva najčešće sklapala među doseljenim stanovništvom, a tek pojedinačni primjeri pokazuju pripadnike domorodačkoga stanovništva, bilo Mikeša ili pripadnika drugih etničkih skupina, što saznajemo preko prezimena, npr. Vlašimsky, Harastijan, Matizalem (vidi tablice 1 i 2 ).

43 Potpuniji tablični prikaz $s$ dužim vremenskim periodom premašio bi okvire ovoga rada.

44 Za potvrdu ovih podataka trebalo bi usporediti podatke iz matičnih knjiga od razdoblja 1890-ih do 1920-ih godina, no takva analiza premašila bi okvire ovog rada.

45 Knjige iz kasnijih razdoblja nisu pregledane.

46 Vladimir Prpić, Matići, Jukini, Podgorje, Virovitica.

47 Ibid. 


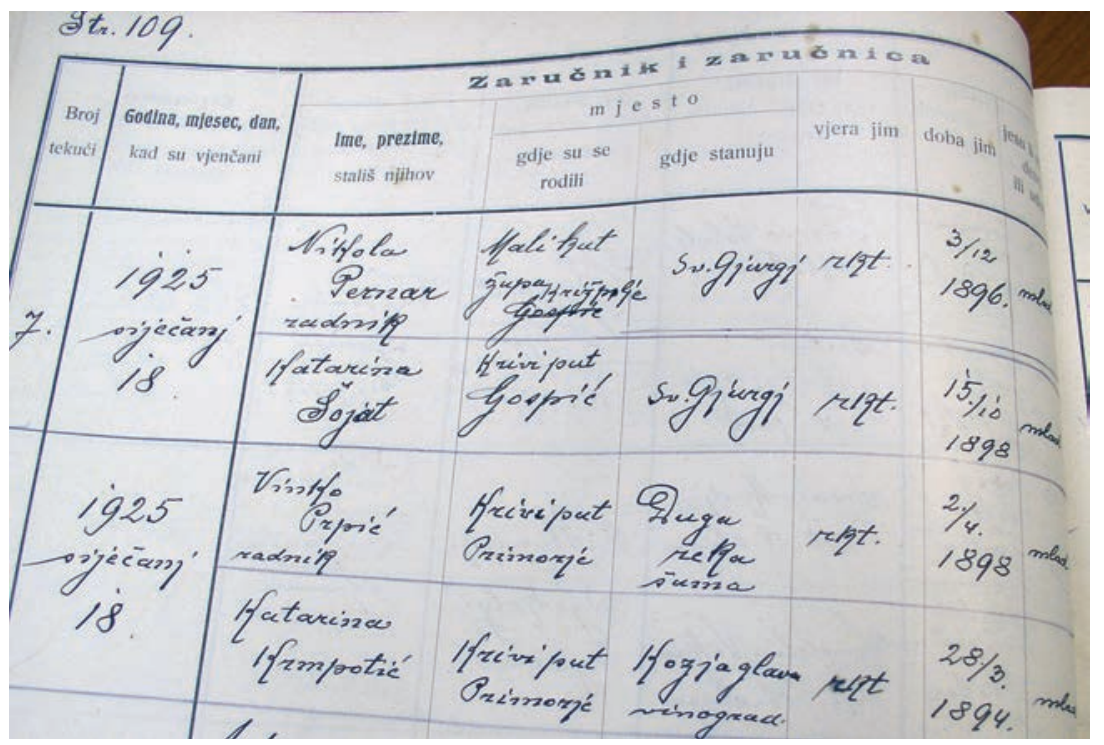

Slika 3: Detalj iz knjige vjenčanih. Matični ured Virovitica; snimila M. Rajković studeni 2006. godine.

\subsection{ODNOS PREMA DRUGIMA}

$\mathrm{N}_{\mathrm{rod}}^{\mathrm{an}}$ astojale smo saznati odnos doseljenoga stanovništva prema drugim skupinama, posebice prema starosjedilačkome (domicilnome) stanovništvu koje se određuje etnonimom Mikeši. Početkom 20. stoljeća, dakle u razdoblju doseljavanja Krivopućana, Virovitica je živjela od promjene konja, ona je bila baš na prometnici, čvorište puteva. Mikeši su tu živjeli u centru, rekao je Josip Prpić (Podgorje, Virovitica).

Naziva Mikešs sami pripadnici ove skupine na svojoj internetskoj stranici pojašnjavaju: Divani se o različitom porijeklu vlastitog naziva. Jedni divane da je naziv Mikeš proistekao iz samohvale "MI KRALJEVI ŠUSTERI" jer su ukazom kao dobri susteri, dobili velike povlastice od Marije Terezije. Drugi divane da je to zbog Mike, poduzetnog kirijaša, za kojeg je kirijalo puno ljudi diljem Slavonije, a kad bi ih pitali čiji ste i odakle ste, oni bi rekli od Mike il' Mikeša iz Virovitice. Treći divane daj to zbog Mike Mandića, gradskog odbornika iz Ljubljanske ulice, koji se furtom bunjo i borjo za bolje, pa kad bi se neko od Virovitičana pobunjo za bolje, kazli bi mu: tis ko onaj Mika Mikeš Mandić. Ondak njeko divani daj to od kneza Schaumburg Lippe što je našima tak kazo, kad su ga nješt išli iskat, da su pravi Mikeši - što bi po češki bilo - mački prepredeni. ${ }^{48}$

$\mathrm{U}$ razgovorima sa sugovornicima doznale smo pak kako su se Mikeši većinom među sobom ženili, Virovitica je bila mala prije i svi su se znali. Razlike su bile najviše po prezimenu. ${ }^{49}$ Kao drugu razliku koja odijeljuje ove dvije skupine kazivači navode govor koji se zadnjih nekoliko desetljeća stapa u jedan, novi govor. Lokalni govor Virovitice stanovništvo naziva "mikeški govor“, a prema nazivu samih stanovnika, „Mikeša“. Stanovništvo koje sebe naziva „Mikešima“ i njihov govor stvoreno je migracijama jezika i kultura. (Vranješ 2005:29). Oni znaju tu i tamo neku riječ ubaciti. Moja punica i tast su Mikeši, e ti kad s njima pričaš umjesto nešta kažu nješta. Ma nema, to se sve izmješalo. Sad oni, Mikeši pokušavaju nešta, al nisu niš posebno, jedino su zajebani i zavidni, kazuje jedan od naših kazivača. Govor kao jednu od komponenti prepoznavanja i razlikovanja od Mikeša prepoznali su i naši kazivači, pa su istaknuli: e, naše je lako prepoznati. Kažu: bilo, mliko, dite. Većina su Bunjevci ikavci. ${ }^{50}$ Josip Prpić Matićin napominje kako sad više ne (razlikuju jedne od drugih/op.a.), to je sad sve dobronamjerno, po prezimenu se zna tko je odakle. Onda vi Bunjevci tamo i tako (smijeh/op.a.). Lokalno stanovništvo ulice mala i velika lička (ulička, ali se u govoru

48 Izvor: www.mikesland.hr/omikesima/mikesi.asp

49 Ivan Filipović Vicinov, Virovitica.

50 Ivan Filipović Vicinov, Virovitica. 
gubi/op.a.) prepoznaju kao Mikeške. Raspoznavanje granica doseljene, migrantske grupe po podrijetlu prepoznaju i sami migranti i pripadnici većinske populacije (Božić, 1998:86.). Ovome u prilog svakako ide i naše iskustvo. Po dolasku u Podgorje i predstavljanju uslijedilo je raspravljanje o podrijetlu prezimena jedne od ispitivačica. Time se provela i svojevrsna provjera podrijetla. ${ }^{51}$ Tek nakon, uvjetno rečeno, provjere i upoznavanja korijenja naši sugovornici postali su opušteniji i raspoloženiji za razgovor. Ova potreba za smještanjem u određenu skupinu svakako je pokazatelj određivanja prema Drugima. Naime, jedan od sugovornika istaknuo je: $O$, pa ti si onda skoro naša, aludirajući na blizinu Krivoga Puta i područja Like odakle su preci ispitivačice. ${ }^{52}$

Prepoznavanje Drugih naglašeno je i prema drugim skupinama koje žive na virovitičkome području. Naime, područje je kroz nekoliko desetljeća naseljavano stanovništvom kako iz drugih regija Hrvatske, tako i drugih zemalja. U Krčevinama su većinom bili iz Krivog Puta, a ovdje je bilo pomiješanih dosta. U Sv. Đurdu je bilo dosta Madara, ovdje je bilo dosta Šokaca i nas Primoraca, e onda Zagoraca, Medimuraca je dosta došlo (...) a čujte dosta je to NDH i Pavelić naselio. On je naselio Zagorce u ta dolje sela, onda su Švabe morali ići van, pa su se Zagorci ovdje udomaćili. ${ }^{33}$ Raspoznavanje Drugih ponajviše se očituje kroz prezimena: a ostala prezimena koja nisu krivoputska, a pa neki su došli iz Bosne. To su Vokić, Kovačević, Blažević, Hanić, Halužan, Polak, Begić, a ima $i$ švapskih prezimena, al kasnije su se svi mješali. ${ }^{54}$ Sad su se poslije ovog rata Bosanci doselili, jedno deset familija (...) pa imamo bosanski jarak ${ }^{55}$

\subsection{KULTURNI PROCESI}

$\mathrm{T}$ ijekom istraživanja potvrdilo se da se u imigracijskim uvjetima javljaju procesi kulturnih promjena pokrenutim preseljenjem skupine ljudi iz njihovih izvornih društava i kulturnih sredina u nova sociokulturna okruženja te stupanj stjecanja sadržaja kulturnih i društvenih vrijednosti i obilježja imigracijskog okruženja (usp. Heršak, 1998, 4-5). U nastavku ovoga odlomka prikazuju se uočeni procesi akulturacije u odnosu na one pojave koje nastaju kada skupine pojedinaca, nositelja različitih kultura, uđu u interakciju s drugom kulturom putem izravnog dodira, što pak pokreće transformaciju izvornih kulturnih modela jedne ili obiju skupina što označava promjene i adaptacije u društvu (usp. Ibid.; Bolaff, 2003: 1-2). U pojedinim primjerima adaptacija je početna faza procesa asimilacije, odnosno procesa kojim pojedinci ili skupine postaju društveno - kulturološki slični drugim kulturnim sredinama, odnosno usvajaju tuđe kulturne i društvene vrijednosti i obilježja ${ }^{56}$.

U prvim danima suživota s domicilnim stanovništvom migratorno stanovništvo donosilo je novitete: Kad su ovi iz Krivog Puta dolazili donosili bi smokve, mendule a ovi to ovdje nisu ni vidjeli. Onda kavu, to su pomorci najviše donosili. Nije toga prije bilo, onda to bake prži kavu u tavi, pa mješaj s malo divke ili prži ječma da je ima više. A ovi tu nisu imali ${ }^{57}$.

Iako se unutarnja migracija često definira kao preseljenje unutar istog kulturološkog i sociološkog prostora, uvijek su vidljive bar poneke kulturološke razlike između dvije skupine stanovništva. No, u ovom radu riječ nije samo o te dvije kategorije jer se kroz tekst osim multikulturalnosti uočavaju i velike doze kulturnih pluralizama. Naime, vidljivo je međusobno prilagođavanje etničkih skupina, točnije dobrovoljno dosezanje zajedničkoga i novoga, ali i njegovanje posebnoga. ${ }^{58}$ Sami migranti uočavali su razlike

51 Radi se o provjeri prezimena (pitanja sugovornika: od kojih Jurkovića? Čija si?) i propitivanju vlastitih korijena.

52 Ovaj citat nije transkribiran ni snimljen, već je cijeli događaj zabilježen kao vlastito/subjektivno iskustvo pri terenskome istraživanju.

53 Vladimir Pavelić Matići, Jukini, Podgorje, Virovitica.

54 Josip Prpić, Matići, Jukini, Podgorje, Virovitica.

55 Josip Pavelić Zozan, Krčevine, Virovitica.

56 Detaljnije vidi u: Heršak, 1998, 12-13; Bolaffi et al., 2003: 19-22.

57 Vladimir Prpić, Matići, Jukini, Podgorje, Virovitica.

58 O kulturnom pluralizmu vidjeti više u: Heršak, 1998: 127; Bolaffi et al., 2003: 183, 185, 219. 
između pojedinih etničkih skupina. Tijekom razgovora isticali su da su ovdje došli zbog boljih uvjeta života i da su stoga spremno prihvaćali novitete kako bi postigli isto. Kroz razgovore uočili smo da su na djecu primjenjivani i procesi enkulturacije ${ }^{59}$. Migranti su poticali i usvajanje kulturnih obrazaca ostalih etničkih skupina iz okruženja u kojem su djeca rasla ne bi li se mladi lakše uključili u društveni milje te imali bolji život, kao što se zrcali iz sjećanja Vladimira Prpića (Podgorje): Moja baka je govorila: "Dico vidite kako je kod njih u Mađarskoj, i kod Švaba tako i mi možemo". Mi smo se odma prilagodavali i radili.

Kazivači druge i treće generacija migranata objašnjavali su da nisu primjećivali razliku između načina gradnje kuća, interijera, te načina života domicilnoga stanovništva. Tome u prilog Vladimir Prpić (Podgorje,) kazao je: Imao sam i kolege i djevojke, družili smo se, nismo gledali tko je tko, al' nisam primjećivo razlike. Mi smo se odma utopili. Ono što je bolje, bolje je. Na pitanje što su preuzimali iz kulturnih inventara drugih etničkih skupina, a što su zadržali iz života u Krivome Putu saznale smo: Jedino kad su se klale svinje ... mi smo odmah prihvatili, al to je sve od Nijemaca ostalo. Mi smo palili (uklanjali dlake, op/a.), doduše, palilo se nekad $i$ tu, al kak su svinje postajale veće tu su šurili vodom, jer veće svinje je bilo lakšs furit. Onda smo obradivali meso, moji su odma to počeli, kobasice, čurke. Jedino što smo pravili kukuruzne divenice (vrsta kobasica, op/a.), evo i sad namjeravamo pravit. To je od kukuruznog brašna, krvi i mesa malo. A čujte to se nije imalo pa se šparalo, $i$ onda nije bilo tih crijeva pa se u krpe spremalo, to je doneseno s Krivog Puta ${ }^{60}$.

Prva generacija migranata zadržala je elemente u dijelovima godišnjih običaja primorskih Bunjevaca. Tako je Vladimir Prpić (Podgorje, Virovitica) objasnio: Mi to sad ne radimo, al se sjećam kad je baka bila živa, onda smo sjekli badnjak sa živog drveta ${ }^{61}$.

Zabilježile smo i prijenos kulturnih elemenata preko bračnih veza na primjeru sira škripavca, bitnog elementa identiteta Krivopućana. ${ }^{62}$ Nakon što smo pitali kazivačicu što sve radi od mlijeka, između ostalog navela je i sir škripavac. "A vi ste Mađarica, tko vas je naučio škripavac raditi?" Kazala je: A naučili su me, djed (od muža), Mara (sestra od muža) (smijeh/op.a.). Na što se nadovezao kazivačicin suprug Vladimir Prpić (druga generacija migranata): A šta vas interesira kak se pravi škripavac, ja znam. To odudara od ustaljenog obrasca podjele muških i ženskih poslova na području Krivoga Puta, kada su u pitanju elementi identiteta migrantskoga stanovnišstva.

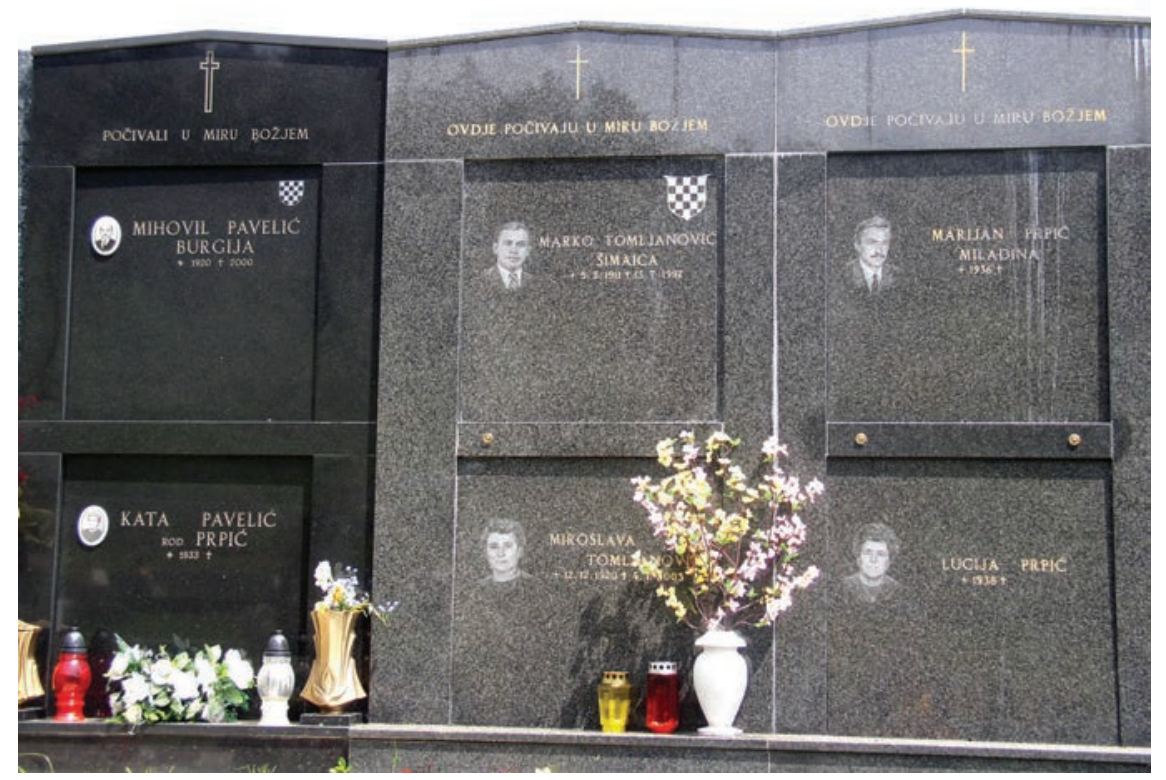

Slika 4: Detalj nadgrobnih spomenika iz groblja u Podbilu (Krivi Put); snimila M. Rajković, kolovoz, 2005.

\footnotetext{
59 O enkulturaciji vidi u: Heršak, 1998: 53; Bolaffi et al., 2003: 87-88.

60 Vladimir Prpić, Matići, Jukini, Podgorje, Virovitica.

61 Vidi članak A. Vlatković: Godišnji običaji primorskih Bunjevaca Krivoga Puta, Senjski zbornik 32, 2005: $317-348$.

62 Usp. Jurković, 2004: 189-212.
} 


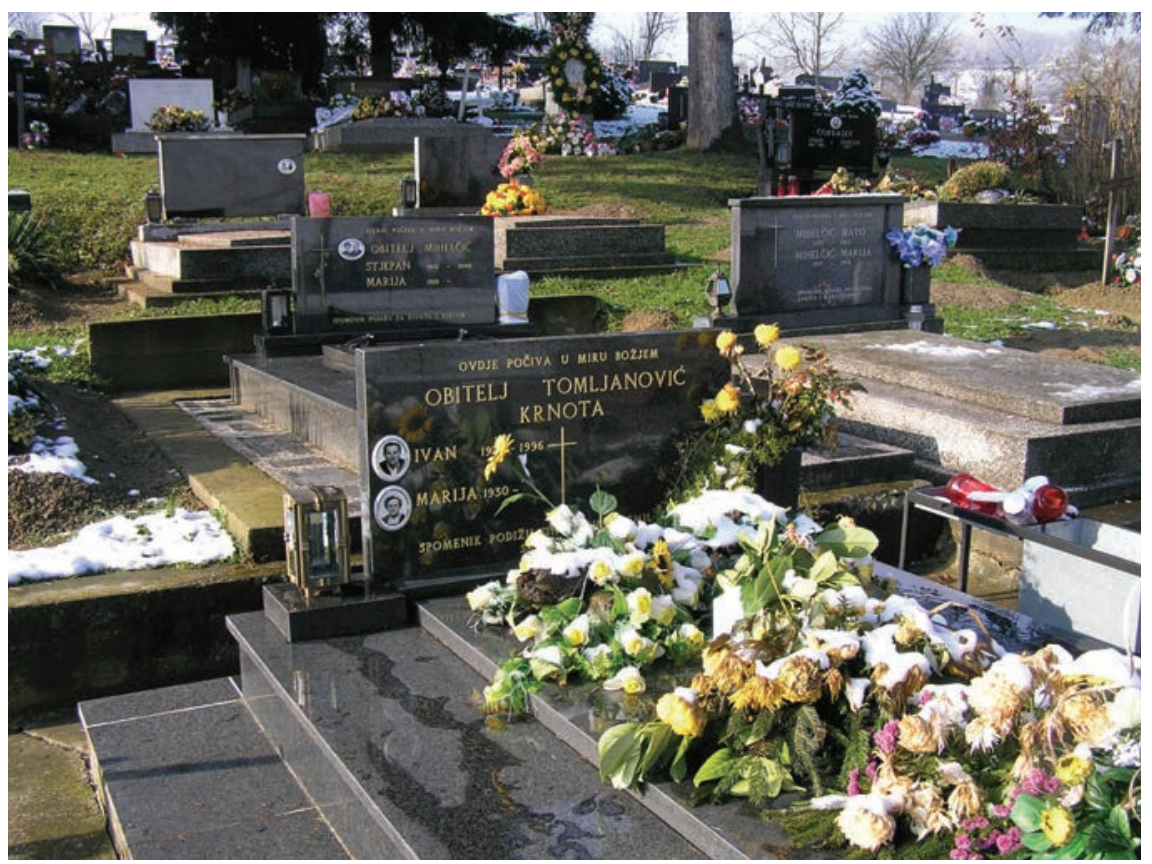

Slikea 4a: Detalj groblja u Kř̌evinama; snimila M. Rajković, prosinac 2005.

U govoru i identifikaciji kako na području Krivoga Puta, tako i na području Virovitice svi upotrebljavaju nadimke ili špicnamete. Svaka osoba ima nadimak, bilo obiteljski ili osobni (katkad i oba) koji se dobio po nekoj istaknutoj osobini ili od upitne zamjenice čiji (npr. Jukini, Markova i sl.). Bilo gdje da odlaze zadržavaju svoj nadimak, no tek u rijetkim slučajevima mijenjaju ga, kao u primjeru Vladimira Prpića: Matići po tati, a ovde smo Jukinovi, a to je po maminom, jer je on bio Jure, Juke, tako su nas zvali tu u Slavoniji, a inače su nas po mami dole zvali Terezini. Bila neka baka Tereza. Nadimci se u većini slučajeva navode i na nadgobnim spomenicima i to na groblju u Podbilu (Krivi Put), te nešto rjeđe na groblju u Krčevinama (sl. 4, 4a).

\section{POVEZANOST S MJESTOM PODRIJETLA (TRANSLOKALIZMI)}

$\mathrm{B}^{\mathrm{u}}$ udući da su na području Krivoga Puta živjeli u mnogočlanim obiteljima ${ }^{63}$, velik dio rodbine ostajao je živjeti na prostoru Krivoga Puta ili selio u druge krajeve Hrvatske ili susjedne države. Pored praćenja integracije migranata u sredinu u koju su doselili, te što im se dogada na novoj destinaciji, antropologa zanima i jesu li ostali povezani s mjestom svog podrijetla $i$ kako (usp. Brettell:2003, 3-5). Na to pitanja daje se odgovor u ovome odlomku. Osim prikaza komunikacije s ljudima koji su ostali u Krivome Putu te samim mjestom, pažnja se posvetila i kontaktima s ostalom raseljenom rodbinom, trendu gradnja kuća za odmor te remigracijama u blizinu Krivoga Puta, odnosno turistički atraktivnije lokalitete.

O kontaktima s rodbinom koja je ostala živjeti na prostoru Krivoga Puta potomci migranata rekli su: Pomagalo se, ako nista javljali su im kad je tu bilo posla da dodu, kad će doć, gdje ima što za kupiti i tako, jer su ljudi jedni drugog povlačili. Teško je bilo tamo živit. ${ }^{64}$ Zbog neadekvatne prometne povezanosti odlasci migranata u Krivi Put tijekom prve polovice 20. stoljeća bili su rijetki.

Jedini primjer obiteljske ispomoći nakon odlaska naveo je Marko Tomljanović Rilac (Mrzli Dol) u odgovoru na pitanje: “Nakon što je vaš brat (oko 1950. te/op.a.) otišao, koliko često je dolazio?” Svake

63 Vidi rad: Milana Černelić, Dvije zadružne obitelji na području Krivoga Puta, Senjski zbornik 27, Senj, 2000: 199216.

64 Vladimir Prpić, Matići, Jukini, Podgorje, Virovitica. 
godino oko Petrove, početkom sedmog miseca, onda mu počni godišnji, on je radio u sudu. On je najviše volio pomoć i njegova žena isto. E onda bi već kosili travu oko Petrove ... kosili, vozili, gonili svašta.

Svi ispitani kazivači na području Virovitice, dakle potomci migranata, barem jednom su posjetili Krivi Put. U ono vreme nije bilo komunikacije, moj otac je pričo kad je prvi put tamo išo s mojim djedom (...) oni su prvo išli vlakom do Rijeke, onda od Rijeke do Senja brodom, pa pješke u Krivi Put, to je bilo prije 1970. A dobro, iša je i moj tata s mojom mamom, onda je tamo prvi put to vidio, ima je dvadesetak godina ${ }^{65}$. Sa sobom često su vodili i žene, pa i kada one nisu bile porijeklom iz Krivoga Puta i djecu. Moj ćaća pokojni, dokje još did bio živ, kaz'o: Ajde ćaća, ima da me odvedeš u moje rodno mjesto! Evo išla i moja supruga. Marijan (sin/ op.a.) je bio četri godine, 1963/4., onda smo prvi put bili dole. Još je bilo tih duša, mi zovemo duše primorske, onda su vikali: Joso, misliš da te ja ne poznam (smijeh/op.a.). Poslije sam bio jedno deset puta, sad je blizo, al nema umrlo je to sve, sad nikog ne poznam. I ljudi su otišli ${ }^{66}$.

Tek nekolicina mladih sugovornika (treća generacija migranata) pokazala je zanimanje za posjet Krivome Putu, pa je Oliver Krmpotić Vuča (Podgorje, Virovitica) istaknuo: Pa kako sad da kažem, meni je jako drago što moji korjeni vuku odande. Ne sad da bi ja otišo dole živjet. Tu sam rođen, tu mi je lijepo i sve, ali nekako srce me i tamo vuče. Osjećam jedan dio sebe tamo. Drago mi je da potječem odande, kad sam to sve vidio i bio, već sam puno godina bio tamo. I nekako priraslo mi je to srcu.

Današnji posjeti Krivome Putu svode se na obilazak ostataka obiteljskih kuća te obilaska groblja. Unatoč tome što su neki migranti, iz primjerice zapadne Europe, napravili obiteljske grobnice u Krivome Putu, te nakon smrti ondje sahranjeni, nismo zabilježile niti jedan takav slučaj kada su migracije bile na područje Virovitice. Razlog tome je, kako kazivači navode, što Krčevine imaju svoje groblje od sredine 20. stoljeća. No prilikom gradnje mrtvačnice u Krivome Putu, potomci Krivopućana financijski su pomogli gradnju iste. Sad kad se gradila tamo mrtvačnica na groblju onda sam ja kupio ovdje novce od svih i slao tamo. Moji su svi tu sahranjeni, a ovi od prije ko bi to sad znao to je više od 100 godina prošlo, kazao je Josip Prpić. Osim odlazaka u Krivi Put ponekad se odlazilo u ova područja i na ljetovanje: Imali smo kumove, prijatelje, znance u Senju na Kozjaku pa smo tamo išli na ljetovanje; oni su iz Krivog Puta. ${ }^{67}$

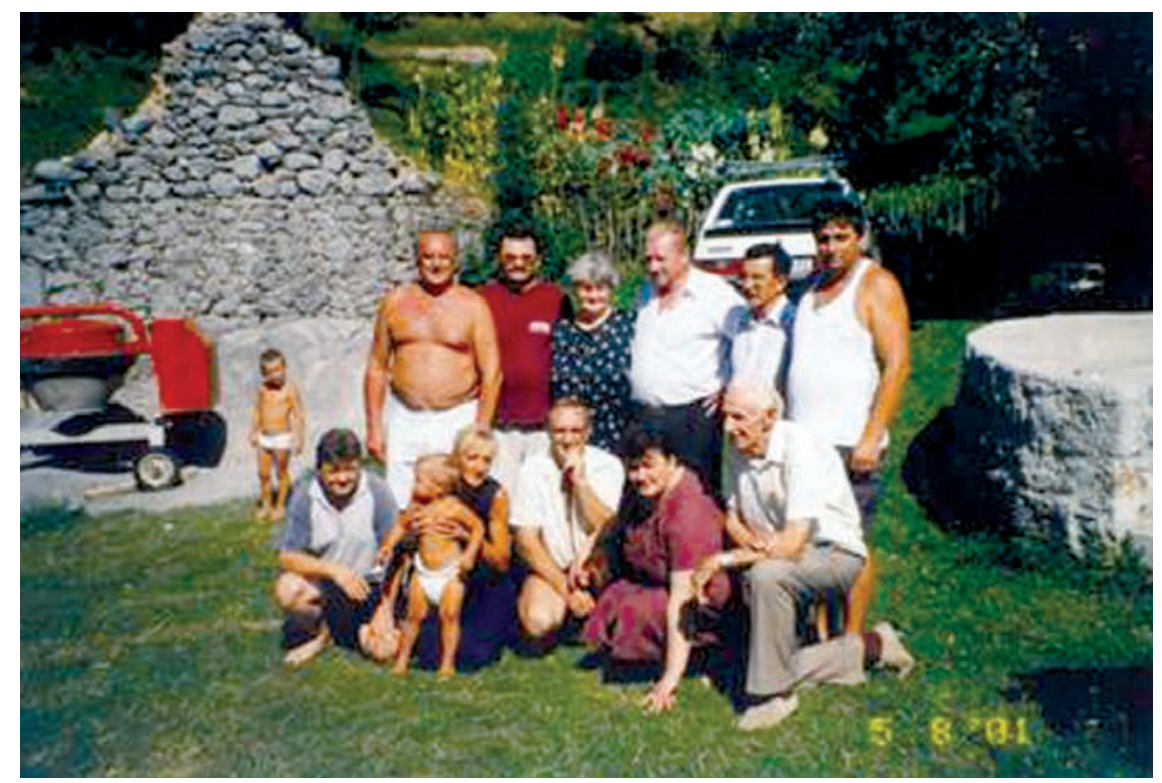

Slika 5: Obiteljsk a fotografija migranata i njihovih potomaka prilikom posjete Krivome Putu 5. kolovoza 2001. godine prilikom obilježavanja Majke Bơ̌je Snježne kojoj je posvećena krivoputska crkva u Podbilu. Iz obiteljskog albuma Olivera Krmpotića Vuče.

65 Josip Prpić, Matići, Jukini, Podgorje, Virovitica.

66 Vladimir Prpić, Matići, Jukini, Podgorje, Virovitica.

${ }_{67}$ Josip Prpić, Maticí, Jukini, Podgorje, Virovitica. 
Mada se neki više ne sjećaju naziva zaselka iz kojeg su im doselili preci, ipak su imali želju otići obići djedovinu. Pojedine obiteljske veze između dalje obitelji izgubile su se u trećoj generaciji migranata, te se danas ponajviše održavaju obiteljske veze na razini Virovitice što je vidljivo na primjeru obitelji Josipa Pavelića Zozana: Osto je tamo još jedan al nismo se čuli, pa smo izgubili veze, a recimo Željkova mama je moja teta. On je u Krivome Putu gradio kuću, pa su mu kazivač i kazivačev brat išli pomagati. Mi smo uvjek išli radit tamo, jer ja i brat smo se zidarijom bavili, pa obidi malo. Onda smo malo u Senju bili, svakako da imaš želju pogledat odakle su ti djed i baka, pa i roditelji.

Nakon uspostave bolje prometne povezanosti sedamdesetih godina 20. stoljeća, porastao je broj dolaska migranata i potomaka u Krivi Put ili Senj. Tako su započeli češći dolasci prilikom vjenčanja i sahrana članova obitelji. Mnogi raseljeni Krivopućani, pa tako i oni s područja Virovitice, nastoje se okupiti u Krivome Putu 5. kolovoza kada se u crkvi u Podbilu slavi blagdan Majke Božje Snježne, zaštitnice Krivopućana $(\text { sl. } 5)^{68}$.

Kontakti se održavaju i s rodbinom izvan domovine pri čemu ih se nastoji upoznati s rodnim krajem: Rodbina iz Njemačke ... dolazili su većinom k nama. A onda kad su upoznali ovaj kraj ... išli su i u Krivi Put. Sad su oni već umrli pa dolaze djeca al rjecte ${ }^{69}$.

Potomci migranata prepoznaju područje Krivoga Puta kao netaknutu oazu prirode koja nudi prirodne lijekove i tradicijsku prehranu. Možda ste bili kod mog strica, Draga i Marko Tomljanović Rilac, i tetke Mire Prpić Ropete tamo odma kod škole (...) prehrana, šta da vam kažem, ja sam imo problema sa želucem i Draga Rilac mi je skuhala neke čajeve, onda u onim Šimeričima neka teta Anka radi pekmeze ${ }^{70}$. Kroz ovaj primjer također možemo uočiti povezanost druge i treće generacije migranata s krajem iz kojih su potekli.

O kontaktima između generacija doseljenika i Krivopućana svjedoči trenutno najčvršća poveznica nogometni klub. A ima, sad ko ima vremena $i$ 'ko je zdrav, ja sam bolestan. Pogotovo sad ovi s nogometom. (dobro su povezani s Krivim Putem/op.a.) Prije nisam mogo od posla (ići u Krivi Put/op.a.). ${ }^{71}$

\subsection{KONTAKTI KROZ NOGOMETNE SUSRETE}

$\mathrm{V}$ eć je ranije u tekstu navedeno kako je suradnja između mještana Krivoga Puta i doseljenih Krivopućana razvijena kroz godišnje nogometne susrete. Razgovori s mještanima Podgorja ponajbolje su pojasnili o kakvoj se suradnji radi. Sin jednoga od pokretača ovih susreta, Oliver Krmpotić Vuča objašnjava: Pa to je moj pokojni otac (Mirko Krmpotićlop.a.), on je, mi smo kao klinci išli snjima na more, dole u Senj i on je htio vit gdje se njegov otac rodio. Onda smo mi to sami tražili i strica je on odavde vodio, Tomu Krmpotića... Krivi Put i zaselak Veljun i onda je on nakon par godina potako inicijativu. U biti predložio nogometnom klubu našem da bi on pokušo uspostaviti kontakte s Krivim Putom. Čuo je da su oni osnovali klub i onda je on njima poslao službeni dopis za suradnju... da jedne godine mi idemo tamo, jedne godine oni vamo i ako ne pristanu na tu suradnju on će pokušati sa drugim nogometnim klubom u blizini (...) oni su odgovorili da oni jesu za to $i$ onda su oni otišli na dogovore. Ovaj iskaz nadopunjuje Drago Cah, tajnik Nogometnoga kluba "Podgorje": Da, osamdeset $i$ sedme godine (1987. započeli susreti/op.a.) i jedini prekid je bio kad je bila Oluja, devedeset $i$ pete $i$ kad je bio napad na Ogulin. (...) E, a kad smo došli tam nismo nikog poznavali. I javili smo se u poštu i jedna starija ženska i Vinko otišo kod nje i kaže: trebo bi Milana Prpića broj. Ona tamo okrene, a ono trideset i dva Milana Prpića imamo u Senju telefon i kaže recite mi kojega. A mi smo dobli informaciju da je nadimak Ropeta. I čim je ovaj rekao Ropeta i nema odma (je pronašla telefonski broj/op.a.). ${ }^{72}$

\footnotetext{
68 Upućujemo na rad koji detaljno obrađuje ovu temu. Marija Kulišić, Ivana Vuković: Majka Božja Snježna u pučkoj pobožnosti na području Krivoga Puta, Senjski zbornik 31, 2004, 239-260, te Rajković, 2004.

69 Vladimir Prpić, Matići, Jukini, Podgorje, Virovitica.

70 Željko Tomljanović Rilac, Podgorje, Virovitica. Teta Anka (ujedno je i brend proizvoda) izlagala je pekmeze na Zagrebačkom međunarodnom velesajmu Eko-etno 2005. godine.

71 Josip Pavelić Zozan, Krčevine, Virovitica.

72 Priča istoga sadržaja ponavlja se i u drugim razgovorima i rado se prepričava kao anegdota.
} 
Velik značaj u susretima dvaju mjesta predstavlja odlazak gradonačelnika Virovitice 11. kolovoza 2006. godine u Senj na utakmicu nogometnih klubova „Bunjevac“ i „Podgorje“ “ ${ }^{73}$ Suradnja utemeljena na nogometnim susretima dobiva novu dimenziju uključivanjem predstavnika grada Virovitice pri čemu više nije naglasak na suradnji migranata nego gradova, Senja i Virovitice. U članku tako stoji: I ovog ljeta vodstvo i igrači Nogometnog kluba "Podgorje" otputovali su kod svojih prijatelja u Krivi Put i Senj. Ova sportska suradnja uspostavljena je 1986. godine na inicijativu pokojnoga Mirka Krmpotića, a budući da u Podgorju i okolici živi dosta gradana koji imaju korijene iz tog dijela Hrvatske, suradnja traje već dva desetljeća. U okviru dvodnevnog boravka jučer su položeni vijenci na groblju u Krivome Putu i na grob legendarnog hrvatskog branitelja Damira Tomljanovića Gavrana, a odigrana je i tradicionalna nogometna utakmica u Krivome Putu. Izaslanstvo grada Virovitice predvodio je gradonačelnik Zvonko Kožnjak, koji se tom prigodom jučer susreo s gradonačelnikom grada Senja i razgovarao o uspostavi još boljih veza između ta dva grada. Oba gradonačelnika izrazila su zadovoljstvo ovom dugogodišnjom suradnjom dvaju nogometnih klubova, ali sljedeći korak mora biti gospodarska i turistička suradnja ova dva grada, istakli su gradonačelnici. (Z.J.) ${ }^{74}$ Iz ovog navoda može se iščitati pomak u dotadašnjim susretima. Prema sugovornicima s virovitičkoga područja to su do 2006. godine bila neobavezna druženja, nogometno zabavni spektakl s tombolom. ${ }^{75}$ Odlaskom službene osobe iz jednog grada susreti više nisu samo nogometna druženja, nego uspostavljanje sportske, kulturne i privredne suradnje gradova Senja i Virovitice. ${ }^{76}$

\subsection{KONTAKTI S DRUGIM BUNJEVAČKIM OGRANCIMA}

$\mathrm{O}$ sim susreta nogometnih klubova, u Podgorju je potaknuta akcija osnivanja Zavičajnoga kluba "Bunjevac" s funkcijom okupljanja Bunjevaca i razmjenom iskustava s Krivim Putem. Među inicijatorima ovog kluba svi sugovornici isticali su preminulog Lolu Prpića (novinar). Vladimir Pavelić Kuzman sjeća se početaka osnivanja Kluba i njegove sudbine: A vidite, ja sam htio radit. Bio je tu neki Lola Prpić, on je htio biti za to. Ja i on smo čak išli u Senj da bi se dogovorili za to, kakav bi žig bio i to... I svi su to prihvatili, $i$ mladi, u hotelu smo Slavoniji (nekada smješten u centru grada /op.a.) radili kad bi dobili prostor da se možemo sastajati. E, neko je htio nekakvu veću slavu, drž ovo, drž ono i to je to. Ljudi su se rastrgali. A, to zbog škrtoće i nesuglasica oko članarine. (...) a kratko je i trajao, i bili smo jednom u Madarskoj, susreli se sa onim ljudima iz Subotice, Vojvodine, jel'. Ali bila je nekakva kriza, pa opet poslije nismo mogli.

Nakon početne inicijative potomaka migranata koji su ujedno imali i društvene funkcije (predstavnici medija i županije), pokušaju uspostavljanja čvršćih veza s ostalim bunjevačkim ograncima pokušale su pridonijeti političke elite devedesetih godina 20. stoljeća. O tome nam je rekao Željko Tomljanović Rilac (dipl. ing. građevine, Podgorje, Virovitica): Bio sam ja u Baji s Tonkovićem, dok je pokojni Vlado Gotovac bio živ. On je ispred Sabora bio zadužen za to. Prpić Lolo, Beljo Ante, ravnatelj Hrvatske matice iseljenika, a to je bilo otprilike kad su se razišli HSLS i LS. Ja sam vozio, iš s autom, a ovi su išli iz Sabora. To nije bila naša inicijativa već iz Sabora, a mi smo nju prihvatili. Ja sam išo kao predstavnik županije. Onda smo dogovorili da će Bela Tonković doć tu u Viroviticu, trebo je bit Bunjevački sabor. Jel plan je bio da se objedine svi Bunjevci, imate Bunjevaca i u Požegi, Đakovu, Osijeku (...) a bio je plan, u početku da se stvori udruga i to je sve palo u vodu. A zašto? Boljka Bunjevaca od davnina, zašto ja to nisam nego ti? Svako sebi vuče zasluge. Ko je dalje bacio kamen.

\footnotetext{
73 Tri internetske stranice donose vijest o susretima, službene stranice Grada: www.virovitica.hr, te nezavisne: www. virovitica-online.com i www.virovitica.net.

74 Izvor: http://www.virovitica-online.hr/vijesti/print_article3665.htm.

75 Ovako je glasila najava u radio emisiji 16. srpnja 2005. na Radio Virovitici. Arhiva GmVtc.

76 Izvor: http://www.virovitica.net/print.asp?clanakID=4680 .
} 
Razgovarajući s kazivačima kod nekolicine postoji želja za uspostavljanjem kontakata s bačkim ogrankom Bunjevaca. Takvu suradnja započela je između primorskih i bačkih Bunjevaca. Ideja je krenula na poticaj pojedinaca, pri čemu su opet potpomogle lokalne političke elite i svećenstvo. Naime, Hrvatska udruga kulture "Lajčo Budanović", Mala Bosna, iz Subotice, gostovala je u Senju i Krivome Putu prilikom proslave krivoputskoga blagdana Majke Božje Snježne 5. kolovoza 2006. godine ${ }^{77}$. Stipan Dulić, tajnik društva o inicijativi kazao je: Rođen sam u Maloj Bosni, 1994. kad je rat bio... nama je ponudena zamjena, pa sam ja zamijenio stambeni objekt u Subotici za Senj i boravim ponekad u Senju. Dogovarao sam sa svećenikom da dodemo ovdje... da se uspostavi suradnja ovih primorskih s Bačkim Bunjevcima. O važnosti gostovanja za bačke Bunjevce isti kazivač je dodao: Put je financirala Republika Hrvatska, preko konzulata najveći dio, jače od polovine... ja bi volio kad bi se to svake godine održavalo, a ujedno bi želio ugošćavati i ovdašnje Bunjevce, ja bi volio... da pokažemo ondašnjim Bunjevcima Hrvatsku kulturu ovih Bunjevaca. A nama je značajno našoj dici pokazati Hrvatsku da bi se to održalo, onda di ćeš ih odvesti, svi žele ić na more. Vam to nije ništa al nam je, to je za njih taki doživljaj da je to neopisivo, evo loše je vrime al to nije važno, oni su se kupali. Vecina od njih je prvi put u Hrvatskoj.

\subsection{GRADNJA VIKENDICA I KUĆA}

Drema podacima iz zadnjeg popisa stanovništva za 2001. godinu na prostoru Krivoga Puta živjelo je 233 stanovnika $^{78}$. Prema našim saznanjima zimi ondje živi još manji broj, budući da se radi o stanovništvu treće životne dobi koje uglavnom odlazi djeci u veća urbana središta (Senj, Novi Vinodolski, Rijeku). Zadnjih dvadesetak godina mnogi obnavljaju stare kuće ili grade nove i ondje borave tijekom ljetnih mjeseci.

Potomci Krivopućana iz okolice Virovitice također prate ovaj trend. Jedan od vlasnika takve kuće je i Željko Tomljanović: Tamo mi je djedovina. Tu di smo napravili kuću tu je bilo guvno gore (...) negdje smo 80- tih napravili kuću, to je slučajno bilo (...) dovezo (građu/op.a.) u Krivi Put i zvao bratiće iz Senja aj dodite pomoć gradit kuću. Oni se najprije uvrijedili kako neću gradit na očevini, već tu gdje je mater rodena, a kad je meni tamo bilo ljepše, ja sam bježo što više od ceste i gledo sam da imam i šternju (spremište za vodu, op/a.)... moj stric Marko, bratić Sré́ko... od kuma dva sina pomagala (...) samo mi je žao što ne mogu više bit gore (...) Nema boljeg mjesta za odmor sam se čovjek mora naviknut na tišinu. Osim što su se zadržali tradicijski obrasci pomoći prilikom gradnje kuća (zvano moba) rođaci pomažu prilikom gradnje stambenih objekata. Kuće za boravak ne koriste isključivo vlasnici, kojih katkada zna biti više, već i šira obitelj, kumovi i prijatelji.

Poneki razmišljaju o gradnji vikendica, ali susreću se s problemima, kao što se vidi u kazivanju Josipa Prpića (Podgorje, Virovitica): Mi smo razgovarali (rodbina/op.a.), mi imamo tamo dio zemlje i razovarali bi da bi napravili nešta tamo obiteljsko... al problem je prijepis, ima te zemlje masu. Tamo ima šuma, al ovaj komad de bi se gradilo dijeli se na nas 4,5 sad jel 'oćemo, nećemo, sad pohvataj oćemo, nećemo, ko bi htio. Čak ako oni i neće, moraś imat i njiove dozvole, pa onda hvatat familiju to je sad svagdje.

\section{TRAJNA VRAĆANJA}

$\mathrm{N}$ ajveći valovi iseljavanja iz Krivoga Puta u bliža urbana središta bili su tijekom šezdesetih godina 20. stoljeća. Ovo iseljavanje prati migracijske trendove što potvrđuju i podaci iz literature za područja ostalih dijelova Hrvatske: Kao točka preokreta uzima se reforma 1965. godine (...) osnovna značajka takvog

Doputovali su u petak 4. kolovoza i otputovali 8. kolovoza. Bili su smješteni kod ljudi u Senju i svećenika. Folklorna sekcija nastupila je u Krivom Putu i Senju, prisustvovali su svetoj misi u Senju, obišli Gradski muzej i tvrđavu Nehaj.

78 Izvor: Državni zavod za statistiku, http://www.dzs.hr/Hrv/Popis\%202001/popis/popis. 
modela se zasniva na masovnom transferu radne snage iz sela u grad, tj. iz poljoprivrede u industriju (Živković et al., 1995:14)79. Većina Krivopućana u navedenom razdoblju odselila je u Senj, u gradsku četvrt Mundaričevac, odnosno Kozjak. Razlog zašto su se gotovo svi preselili u isti kvart objasnio je Zlatko Tomljanović Pešo (Senj): Pomodarstvo, jedan je napravio kuću u Senju pa drugi i treći bitno da je krenulo. Osim radnih migranata u obližnja urbana mjesta, pedesetih godina 20. stoljeća i ranije, u Senj uglavnom su selili mladi radi potreba srednjoškolskog obrazovanja, nakon čega bi ondje ostajali živjeti ${ }^{80}$.

Vladimir Pavelić (Podgorje, Virovitica) na pitanje o povratku u Krivi Put odgovara: A moji nisu (poželjeli vratiti se u Krivi Put/op.a.), ali pokojna baka je govorila, mamina mama, inače je prirodno bila inteligentna, nije išla u školu ali je znala čitat, a to si jedan drugog učio. E, kaže ni mrtvu me gore nemojte vodit. Neimaština i glad, koje su bile prisutne početkom 20. stoljeća na primorskome području, ostavile su neizbrisiv trag među prvom skupinom migranata. No već u drugoj generaciji migranata zabilježile smo promjenu mišljenja. Kazivači iz Virovitice naveli su primjere kasnijih remigracija i to odlazaka u Senj. Zanimljivo je što su se i oni kao i većina Krivopućana smjestili u isti dio grada Senja: Šolići su, kad je Marko oša u penziju 1965., otišli natrag dole živjet radi zdravlja ... on je bio star ko moj otac (rođen početkom 20. stoljeća, op.a.), on je bio meni krsni kum (...) obolio tu na te bronhe ... otišo u Senj i napravio si kuću i doživio 90 godina. Onda je otišo njegov brat jedan pa drugi, sobiteljima, bilo je njih ovdje petero braće i dvi sestre (...) s djecom su otišli tamo. Oni su gore iznad benzinske, taj dio se zove Kozjak. Odma prou cestu (ulicu) ima Marijan, a drugu ovaj drugi, tamo su sve krivopućani naseljeni ${ }^{81}$.

Razgovarajući s kazivačima često su navodili raseljenu rodbinu i česte remigracije. Stječe se dojam da im preseljenje nekoliko puta tijekom života ne predstavlja nikakav problem što potvrđuje karakteristiku ove regije, pa i čitavu Ličko-senjsku županiju kao prostor izrazite migracijske mobilnosti stanovništva. Jedna od mnoštva migrantskih priča je i obitelji Filipović: Djed je bio u Americi osam godina i to u Kanadi (otišo je 1906), najprije je došo u Ameriku, pa je ošo tako malo po malo za poslom u Kanadu. Bio je 1888. godiste, a 1984. je umro s 96 godina. On je 1908. gradio prugu Princ Rubert-Vankuver ... cijelo je vrijeme radio na toj pruzi. 1914. je došo kući (...) onda se oženio, i stric taj što je još uvjek živ, što živi u Škrljevu je roden 1919. godine, onda je 1924. došo moj otac (...) svi su se rodili kasnije tu (na području Viroviticel op.a.), al su kasnije (nakon 1945. godine/op. a.) odlazili živjet u Rijeku i ̌̌krljevo ${ }^{82}$.

Svi kazivači isticali su da su zadnjih dvadesetak godina popularne remigracije u turistički atraktivnija mjesta u blizini Krivoga Puta: Al ljudi su se dosta i vratili, ljudi su otišli dole, a čujte sad je tamo bolje, al ne gore na brdo već dolje u Senj, Novi Vinodolski i okolo ${ }^{83}$.

\section{ZAKLJUČNA RAZMATRANJA}

U Tradu se prikazuje studija slučaja homogene migracije zbog ekonomskih razloga na primjeru preseljenja dijela Krivopućana iz ruralnog prostora s obronaka primorske strane podno Velike Kapele u također ruralni prostor u drugu regiju Republike Hrvatske, okolicu Virovitice. Migracije iz Krivoga Puta bile su dobrovoljne; u početku privremeni (najčešće sezonski) odlasci manjih skupina uglavnom mladih muškaraca. U periodu od dvadesetak godina počinju se pretvarati u trajna preseljenja, a posebice je na to utjecao postupan dolazak djevojka, odnosno žena i formiranja obitelji. Odlazak za nekim tko na bilo koji

\footnotetext{
79 Mjera gospodarske politike prema selu i poljoprivredi djelovala je destimulirajuće na razvoj poljoprivrede i ostanak na selu. Prometna izoliranost, nedostatak agrarne infrastrukture, kulturnih sadržaja, te slabi razvoj društvenih djelatnosti temeljni su potisni činitelji deagrarizacije i deruralizacije.

80 Usporedi: Rajković 2004:272-273.

81 Vladimir Prpić, Matići, Jukini, Podgorje, Virovitica.

82 Dinko Filipović Vicinov, Virovitica.

83 Vladimir Prpić, Matići, Jukini, Podgorje, Virovitica.
} 
način privlači aktera migracija dovodi do stvaranja mreža i migracijskih valova. U ovom slučaju rezultiralo je formiranjem novog dijela naselja Rezovac, nazvanog Rezovačke Krčevine.

Najveći potisni činitelji ujedno su bili i najveći privlačni činitelji, bolje ekonomske mogućnosti u drugoj sredini, stjecanje bolje naobrazbe i bolji uvjeti rada, bolji životni uvjeti. Glavni razlog raseljavanja Krivopućana bila je ekonomska stagnacija poljoprivrede, nepostojanje infrastrukture i komunikacije s bližim urbanim centrima.

Unutarnje migracije su one pri kojima pojedinci ostaju u sklopu istog socio-kulturnog-političkog prostora, ali se geografski kreću (Živković et al., 1995:10). No u ovom radu vidljivo je da imigranti i kod unutarnje migracije prolaze cijeli niz procesa prilagodbe u novoj okolini. Koliko će trajati prilagodba, kakav će biti način i stupanj integriranosti u novu okolinu ovisi o nizu faktora. Osim kazivanja migranata i njihovih potomaka mnogobrojni podaci, kako o ovim temama tako i mnogim drugim, dobiveni su iz matičnih knjiga (rođenih, krštenih, vjenčanih). Istraživanje pokazuje da je najveći broj prve generacije migranata (a većim dijelom i druge generacije) sklapao brakove između sebe, kao i kumstva te time činio socijalne poveznice i (ne)svjesne simboličke granice društvenih zajednica. Trebalo je dvadesetak godina da migranti mogu kao mjesto stanovanja navesti ulicu i kućni broj, odnosno da se integriraju kao ravnopravni građani. Ova dva naselja dobila su infrastrukturu (ceste, struju) tek 70-ih godina 20. stoljeća. No danas stanovnici ovih naselja ističu da žive u poželjnom prostoru: Jel smo atrakcija što smo blizu grada, al opet je mir, imaju ceste i sve, a opet je priroda ${ }^{84}$. Kao jedan od ciljeva istraživanja bilo je saznati i današnju povezanost migranata i njihovih potomaka s lokalnom zajednicom, u ovom primjeru s Krivim Putem. Geografska udaljenost odlaska od domicilnog prostora u pravilu određuje kontinuitet i intenzitet veza sa srodnicima, prijateljima i cijelim socijalnim i kulturnim miljeom iz kojeg su migranti došli. Fizička komunikacija raste nakon 70-ih godina 20. stoljeća kada je poboljšana prometna povezanost.

U imigracijskim uvjetima javljaju se procesi kulturnih promjena pokrenutim preseljenjem skupine ljudi iz njihovih izvornih društava i kulturnih sredina u nova sociokulturna okruženja (usp. Heršak, 1998, 4-5). Ova studija slučaja potvrđuje da se isti procesi događaju i kada je u pitanju unutarnja migracija. No, na području Virovitice uočavamo da odnos nije bio samo između dvije skupine stanovništva, uobičajeno migratorne i domorodačke. Naime, na ovom prostoru žive brojni pripadnici raznih nacionalnih manjina i stanovnika različitih regionalnih provenijencija, primjerice Mađari, Nijemaci, Zagorci, Šokci, Bosanci, stoga pronalazimo kulturnu pluralnost. Danas oni međusobno prepoznaju i njeguju pojedine segmente svoje kulture. No paralelno usvajaju obrasce drugih kultura, te ženidbenim vezama prenose elemente jedne kulture, preko druge u treću kulturu. Kroz rad uočavamo procese akulturacije i asimilacije, ali i da je u procesima konsolidacije ova bunjevačka subetnička skupina zadržala subjektivni osjećaj identiteta. Potomci Krivopućana pokazuju određene svojstvenosti koje ih razlikuju od domicilnoga stanovništva, kao što je to primjerice slučaj kod govora gdje se povlače različitosti vlastite skupine od starosjedioca Mikeša. Zatim, prepoznavanje kod prezimena i obiteljskih nadimaka što nije zabilježeno kod ostalih skupina ovoga područja. Tijekom razgovora kazivači su isticali pripadnost bunjevačkoj skupini ${ }^{85}$. Djelomično se pripadnost skupini odražava i kroz nogometne susrete. Na internetskoj stranici sela Podgorje spomenuto je tek u jednoj rečenici doseljenje iz Like i Gorskog kotara ${ }^{86}$. Ovo može ukazivati na činjenicu da se svijest o pripadnosti ipak gubi s daljnjim generacijama migranata, dok pak kod nekih raste osjećaj pripadnost. Odnos prema mjestu porijekla zaista je individualan. Sjetimo se migrantice koja je kazala: Ni mrtvu me nemojte gore vodit. U drugim primjerima su migranti koji su i nakon preseljenja barem jednom godišnje odlazili u Krivi Put, te inicirali jednogodišnje posjete, u početku preko nogometnih susreta. Inicijativa mi-

\footnotetext{
84 Josip Prpić, Matići, Jukini, Podgorje, Virovitica.

85 Tema u kojim segmentima društva se ova skupina predstavlja kao Bunjevci ili njihovi potomci ostaje za neki budući rad.

86 Usp. www.podgorje.net/povijestpodgorja.php
} 
granata privukla je i potporu političkih elita (bilo gradonačelnika ili saborskih zastupnika), a budućnost će pokazati hoće li to potaknuti jačanje svijesti o pripadnosti bilo kraju iz kojeg su porijeklom, odnosno bunjevačkom ogranku (primorski Bunjevci) ili cjelovitoj bunjevačkoj skupini. U ovim temama vidljiva je važnost pojedinačnoga pristupa svakom pojedinom migrantu, odnosno potomku. Naime, neki su se nakon mirovine preselili u Senj, neki obnavljaju stare kuće u Krivome Putu ili grade vikendice. Prilikom boravka nekoliko dana u Virovitici, pročuo se glas da radimo intervjue s potomcima Krivopućana, nakon dva dana pojedinci su sami zvali u Muzej Viroviticu i pitali kad bismo mogli s njima razgovarati, budući da i oni imaju nešto za reći ${ }^{87}$.

\section{LITERATURA}

ADAMČEK, Josip (1986): Prilozi povijesti Virovitice (od sredine 18. do sredine 19. stoljeća), Virovitički zbornik 1234-1984, Virovitica, 157-179.

BOŽIĆ, Saša (1998): Etničnost migracijskih zajednica: nastajanje novih manjina, u:ur.R.Čičak-Chand i J. Kumpes, Etničnost, nacija, identitet - Hrvatska i Europa, Zagreb, 85-100.

BOLAFFI, Guido, Rafaele Bracalenti, Peter Braham and Sandro Gindro (2003): Dictionary of Race, Ethnicity \& Culture, Sage Publications, London, Thousand Oaks, New Delhi.

BRETTEL, Caroline (2003): Antropology and Migration. Essays on Transnationalism, Etnicity and Identity. Altamira Press, A Division of Rowman \& Littlefield Publishers, Inc. Walnut Greek, Lanhan, New York, Oxford. str.1-7.

CASTELS, Stephen \& Mark J. Miller (2003): The age of Migration. Palgrave Macmillan, str.278-286.

COHEN Robin (ed.) (1995): Contents i Part one-Prologue. U: The Cambridge Survey of World Migration, Cambridge University Press, str. 1-9.

ČAPO, Jasna (1988): Etnologija između demografije i socijalne historije, Etnološka tribina 11, 5-16.

ČAPO ŽMEGAČ, Jasna, Valentina Gulin Zrnić, Goran Pavel Šantek (2006): Etnologija bliskoga: Poetika i politika suvremenih terenskih istraživanja. U: Etnologija bliskoga: Poetika i politika suvremenih terenskih istraživanja. (ur.) Čapo Žmegač, Jasna, Valentina Gulin Zrnić, Goran Pavel Šantek, Institut za etnologiju i folkloristiku, Zagreb, 35-42.

ČERNELIĆ, Milana (2005): Pristupi istraživanju bunjevačkih identiteta, Studia ethnologica Croatica, vol 17, Zagreb, 25-47.

HERŠAK, Emil (1998): Leksikon migracijskog i etničkog nazivlja, Institut za migracije i narodnosti, Školska knjiga, Zagreb

HORVAT, Rudolf (2001): Povijest grada Virovitice, Matica Hrvatska, Virovitica.

HORVAT, Zvonimir (2002): Šumske željeznice u Hrvatskoj (2), u: Hrvatske šume, broj 63, ožujak, 3435.

JONJIĆ Pavao (ur.) (1998): Uvod. U: Izvješća iseljeničkog komesarijata u Zagrebu 1922.-1939. , Institut za migracije i narodnosti, Zagreb, 5-9.

KORENČIĆ, Mirko (1979): Naselja i stanovništvo SR Hrvatske 1857-1971., JAZU, knjiga 54., Zagreb.

LAJIĆ, Ivan (ur.) (1998): Predgovor. U: Migracije u Hrvatskoj regionalni pristup, Institut za migracije i narodnosti, Zagreb, 7-9.

MESIĆ, Milan (2002): Međunarodne migracije, tokovi i teorije. Zagreb, Zavod za sociologiju Filozofskog fakulteta u Zagrebu. Biblioteka Societas.

87 Unatoč tome što se u novijim etnološkim radovima prakticira zaštita identiteta kazivača (usp. Čapo Žmegač et al., 2006: 35-42) u ovom članku odlučile smo navesti podatke budući da su kazivači to željeli. U nekoliko iskaza identitet je prikriven odlukom autorica. 
PAVLICA, Dane (1986): Razvoj školstva i prosvjete u virovitičkom kraju, Virovitički zbornik 1234-1984, Virovitica, 463-472.

PAVLIČEVIĆ, Dragutin (1986): Prilog poznavanju agrarnih odnosa u virovitičkom kotaru potkraj 19. i početkom 20. stoljeća, Virovitički zbornik 1234-1984, Virovitica, 185-194.

RAJKOVIĆ, Marijeta (2004): Prilozi poznavanju migracija Krivopućana. Senjski zbornik 31, 261-286.

RAGUŽ, Mirko (1990): Osnovna škola Krivi Put, Senjski zbornik 26, 343-360.

SABLJAK, Tomislav (2001): Rječnik hrvatskog žargona, Biblioteka Lexica, Zagreb, 224.

TARI, Dragutin (1986): Prilozi za poznavanje razvoja drvne industrije u Virovitici, Virovitički zbornik 1234-1984., Virovitica, 581-590.

UROIĆ, Marija, Antun HURM, (1994): Njemačko-hrvatski rječnik s gramatičkim podacima i frazeologijom, 2. izdanje, Školska knjiga, Zagreb, 655.

VRANJEŠ, Karlo (2005): Virovitički („mikeški“) govor, u: Zavičaj - časopis ogranka Matice Hrvatske u Virovitici, Virovitica, 29-30.

ŽIVKOVIĆ, Ilija, Željka ŠPORER, Duško SEKULIĆ, (1995): Asimilacija i identitet, Školska knjiga, Zagreb, 10-18.

\section{IZVORI}

Knjige rođenih i krštenih br. 403 (od 1917. do 1922. godine), br. 404 i 405 (od 1922. do 1931. godine). Matični ureda Virovitica.

Knjige Indeksa rođenih (od 1908. do 1925., od 1926. do 1934., te od 1935. do 1945, Mjesni ured Suhopolje.

Vjenčanik 1904.-1923. (knjiga 446) i Vjenčanik 1923.-1939. (knjiga 447). Mjesni ured Suhopolje.

Zavičajnik mjesta Rezovac (sastavljen je na osnovu starih popisa zavičajnika i listina domaćinstava koje su sastavljane povodom Općeg popisa stanovnika 1932. godine). Općina Suhopolje.

Jurković, Jasmina (2005-2006): Transkripti s terenskih istraživanja virovitičkih Bunjevaca, Arhiv Gradskog muzeja Virovitica.

Rajković, Marijeta (2002-2006): Transkripti s terenskih istraživanja na području Krivoga Puta. Arhiv Odsjeka za etnologiju i kulturnu antropologiju, Filozofski fakultet Zagreb.

Rajković, Marijeta (2006): Transkripti s terenskih istraživanja virovitičkih Bunjevaca, Arhiv Odsjeka za etnologiju i kulturnu antropologiju, Filozofski fakultet Zagreb i Arhiv Gradskog muzeja Virovitica.

\section{INTERNETSKE STRANICE}

www.dzs.hr/Hrv/Popis\%202001/popis/popis. (zadnji puta posjećeno 5.11.2006.)

www.imin.hr/page/index.aspx?r=2\&r1=11 (zadnji puta posjećeno 5.11.2006.)

www.mikesland.hr (zadnji puta posjećeno 8.11.2006.)

www.virovitica.hr (zadnji puta posjećeno 8.11.2006.)

www.virovitica-online.com (zadnji puta posjećeno 8.11.2006.)

www.virovitica.net (zadnji puta posjećeno 8.11.2006.)

www.podgorje.net (zadnji puta posjećeno 8.11.2006.) 